

\title{
Degradation of Ni-YSZ Electrodes in Solid Oxide Cells: Impact of Polarization and Initial Microstructure on the Ni Evolution
}

F. Monaco, M Hubert, J. Vulliet, J P Ouweltjes, D Montinaro, P. Cloetens, P. Piccardo, F. Lefebvre-Joud, J. Laurencin

\section{To cite this version:}

F. Monaco, M Hubert, J. Vulliet, J P Ouweltjes, D Montinaro, et al.. Degradation of Ni-YSZ Electrodes in Solid Oxide Cells: Impact of Polarization and Initial Microstructure on the Ni Evolution. Journal of The Electrochemical Society, 2019. hal-02572214

\author{
HAL Id: hal-02572214 \\ https://hal.science/hal-02572214
}

Submitted on 13 May 2020

HAL is a multi-disciplinary open access archive for the deposit and dissemination of scientific research documents, whether they are published or not. The documents may come from teaching and research institutions in France or abroad, or from public or private research centers.
L'archive ouverte pluridisciplinaire HAL, est destinée au dépôt et à la diffusion de documents scientifiques de niveau recherche, publiés ou non, émanant des établissements d'enseignement et de recherche français ou étrangers, des laboratoires publics ou privés. 


\title{
Degradation of Ni-YSZ Electrodes in Solid Oxide Cells:
}

\section{Impact of Polarization and Initial Microstructure on the Ni Evolution}

\author{
F. Monaco ${ }^{1 \text { z }}$, M. Hubert ${ }^{2}$, J. Vulliet ${ }^{3}$, J.P. Ouweltjes ${ }^{4}$, D. Montinaro ${ }^{5}$, P. Cloetens ${ }^{2}$, \\ P. Piccardo ${ }^{6}$, F. Lefebvre-Joud ${ }^{1}$, J. Laurencin ${ }^{1}$ \\ ${ }^{1}$ Univ. Grenoble Alpes - CEA/LITEN, 38054, Grenoble, France \\ ${ }^{2}$ European Synchrotron Radiation Facility (ESRF), 38000, Grenoble, France \\ ${ }^{3}$ CEA, DAM, Le Ripault, F-37260, Monts, France \\ ${ }^{4}$ SOLIDpower S.A., 1400, Yverdon-les-Bains, Switzerland \\ ${ }^{5}$ SOLIDpower S.p.A., 38017, Mezzolombardo, Italy \\ ${ }^{6}$ Department of Chemistry and Industrial Chemistry, University of Genoa, Genoa 16146, \\ Italy \\ ${ }^{z}$ Corresponding author: Telephone: $+33(0) 438780198$, Fax: $+33(0) 438784139$, \\ E-mail: federico.monaco@cea.fr
}

\begin{abstract}
Two types of solid oxide cells with different Ni-YSZ cermet microstructures have been aged in electrolysis and fuel cell modes for operating times ranging from 1000 to 15000 hours. The pristine and aged cermets have been reconstructed by synchrotron X-ray holotomography. Nickel agglomeration has been observed in the bulk of the operated samples inducing a significant loss of triple phase boundary lengths. The inspection of the microstructural properties has confirmed the stabilizing role of YSZ on Ni coarsening. Furthermore, the gradients of properties quantified at the electrolyte interface have revealed a depletion of $\mathrm{Ni}$ only in the electrochemically active region of the electrode. The process is strongly promoted for a coarse cermet microstructure when operated under electrolysis current. The evolution of the microstructural properties has been implemented in an in-house multiscale model. The simulations have shown that the loss of performance is dominated by the depletion of $\mathrm{Ni}$ in case of a coarse microstructure. Thanks to the computations, it has been shown that the $\mathrm{Ni}$ depletion is controlled by the cathodic overpotential. To explain this dependency, it has been proposed that the accumulation of oxygen vacancies in the double layer could deteriorate the $\mathrm{Ni} / Y S Z$ interface and trigger the Ni depletion.
\end{abstract}




\section{Introduction}

Solid oxide cells (SOCs) are electrochemical devices operating at high temperature that can directly convert fuel into electricity (fuel cell mode - SOFC) or electricity into fuel (electrolysis mode - SOEC). In recent years, the interest on SOCs has grown significantly thanks to their wide range of technological applications that could offer innovative solutions for the transition toward a renewable energy market. For example, this high-temperature electrochemical device could be associated to wind turbines or solar panels for the clean production of hydrogen. In fuel cell mode, the SOCs are typically used for the generation of heat and electricity for residential $\mu \mathrm{CHP}$ systems (micro Combined Heat and Power) [1-3]. Moreover, the SOCs present various advantages, such as a good reversibility, a large fuel flexibility and a very high efficiency without the use of expansive catalysts.

Nowadays, the typical material for the dense electrolyte is Yttria-Stabilized Zirconia (YSZ). The electrolyte separates the hydrogen electrode, made of a cermet in nickel and YSZ (NiYSZ), and the oxygen electrode, usually constituted by Mixed Ionic and Electronic Conductors (MIECs), such as Lanthanum Strontium Cobaltite Ferrite (LSCF). To limit the reactivity between the oxygen electrode and the electrolyte, a thin barrier layer made of Gadoliniumdoped Ceria (GDC) is sandwiched between the two [4,5]. It has been recently proposed to replace LSCF by a composite of LSCF and GDC as an alternative oxygen electrode, in order to mitigate the mismatch in thermal expansion coefficients between the electrode and the electrolyte [6] and to enhance the electrode performances, especially in electrolysis mode [7].

Despite of all their advantages, the performance degradation of SOCs is still too high to envisage the industrial deployment of this technology [8,9]. Indeed, the degradation rates should be limited to less than $0.5 \% \cdot \mathrm{kh}^{-1}$ to reach commercial attractiveness, while it is still in the range of $\approx 1-3 \% \cdot \mathrm{kh}^{-1}$ in SOFC mode and between 2 and $10 \% \cdot \mathrm{kh}^{-1}$ in SOEC operation [10]. These rather large degradation rates are caused by various aging phenomena activated by the high operating temperatures such as the electrode microstructural evolutions, the chemical instabilities of materials and the inter-diffusion of elements between the cell components [1113].

The main degradation mechanisms occurring in the cells are the chemical destabilization of the oxygen electrode $[14,15]$, the diffusion of cations and $\mathrm{Ni}$ in the electrolyte and the formation nanopores leading to decrease its ionic conductivity $[16,17]$ and the morphological evolution of $\mathrm{Ni}$ within the hydrogen electrode [18]. This latter phenomenon represents a significant contribution to the global cell degradation [19]. Indeed, it has been shown that the Ni-YSZ cermet is subjected under operation to a Ni agglomeration resulting in a phase coarsening and a migration changing the Ni distribution in the electrode [18-32].

The Ni agglomeration is characterized by an increase of the Ni mean particle diameter $\left(\overline{\mathrm{D}}_{\mathrm{m}}\right)$ due to the sintering of the smallest particles. This phenomenon yields a loss of active Triple Phase Boundary lengths (TPBls) [23,25,28] defined by the lines where the percolated gas, electronic (Ni) and ionic (YSZ) phases meet. As they represent the electroactive sites where the charge transfer reactions take place [33-35], Ni agglomeration induces a significant decrease in cell performance that could explain around $30 \%$ of the total cell degradation after 2000 hours [18]. It has been shown by several authors that this phenomenon is purely thermally 
activated and independent on the electrode polarization [18,23,27,29,30]. Indeed, it has been proposed that Ni coarsening is ascribed to an Arrhenius-type Ostwald ripening process that could be associated to surface or bulk solid-state diffusion of $\mathrm{Ni}$ [18]. However, the role of the electrode microstructure remains nowadays unclear. Indeed, it has been suggested that the YSZ backbone could limit the Ni coarsening [18,23,36]. This inhibiting effect of the YSZ network could be explained by the interfacial adhesion between Ni and YSZ that could stabilize and prevent Ni from a massive agglomeration at high temperature [18].

In parallel to the agglomeration, a process of Ni migration has also been observed leading to change the Ni repartition within the electrode. This phenomenon is restricted to the electrode active layer where the electrochemical reactions take place. It is associated to a migration of $\mathrm{Ni}$ towards the bulk of the electrode and results in a significant Ni depletion at the electrolyte interface. The Ni depletion is accompanied by a loss of active TPBls close to the electrolyte interface that can induce a significant degradation of the electrode and cell performances. However, despite its critical importance, the contribution of $\mathrm{Ni}$ depletion on the electrode and cell degradation rates has never been quantified precisely.

In terms of operating conditions, Ni migration has been observed after aging in SOEC operation [21,22,31,37,38] or SOFC mode [29,39]. However, some experimental results suggest that the severity of the phenomenon could be aggravated under electrolysis conditions because of the high cathodic overpotential [21,22]. In addition, it has been reported that the high steam partial pressures could accelerate the process [40]. To date, the role of temperature or the initial cermet microstructure remains unclear and even contradictory with the statements observed for the Ni coarsening in the bulk. For instance, a fine microstructure in the active layer could help to mitigate the rate of $\mathrm{Ni}$ migration [41]. Therefore, in spite of many experimental efforts, the exact role of the operating conditions, the electrode polarization and the microstructure on the Ni redistribution is still not precisely established.

For all these reasons, the origin of $\mathrm{Ni}$ migration is also not completely understood. Nevertheless, it has been proposed that the mechanism is based on the formation of $\mathrm{Ni}(\mathrm{OH})_{\mathrm{x}}$ gaseous species to take into account the role of high steam partial pressure $[32,42,43]$. Furthermore, in order to explain the depletion in the active layer observed especially in electrolysis mode, it has been proposed that Ni migration could be associated to a contact loss between Ni and YSZ that could be triggered by high cathodic overpotential [37].

In this work, we propose to better understand the underlying mechanisms involved in the $\mathrm{Ni}$ agglomeration and depletion in order to assess their impact on the electrode and cell response. For this purpose, the cermet microstructures of two typical cells have been reconstructed by synchrotron X-ray nano-holotomography after operation. The cells present different microstructures and were aged in fuel cell or electrolysis mode with aging times ranging from 1000 to 15000 hours. Special attention has been paid to analyze the microstructural evolution at the electrolyte interface as function of the operating conditions and the initial cermet microstructure. These microstructural data have been implemented in an in-house multiscale model including a detailed reactions kinetics for both electrodes [44-46]. The model has been used to simulate the impact of $\mathrm{Ni}$ agglomeration and depletion on the electrode and cell response. Thanks to the modeling approach, the potential causes of the Ni depletion are 
discussed and a possible mechanism for the loss of adherence between Ni and YSZ is suggested.

\section{Cells Description and Experimental Results}

\section{Materials and Geometries}

Two types of classical hydrogen electrode supported cells, named $C e l l-A$ and $C e l l-B$, have been analyzed in this work and are shortly described hereafter (Fig. 1).

The dense electrolyte of Cell-A has a thickness of $\approx 8 \mu \mathrm{m}$ and is made of Zirconia Stabilized with $8 \mathrm{~mol} . \%$ of Yttria (8YSZ). The porous hydrogen electrode is a Ni-YSZ cermet of $\approx 260$ $\mu \mathrm{m}$ while two variants for the thin oxygen electrode are considered. On the one hand, the oxygen electrode of Cell-A1 presents a multilayer structure with a thickness of $\approx 60 \mu \mathrm{m}$. This assembly is composed of a GDC-LSCF composite associated to a LSCF layer topped by a current collector made of Lanthanum Strontium Cobaltite (LSC). On the other hand, Cell-A2 presents an oxygen electrode constituted by a single layer in LSC $(\approx 75 \mu \mathrm{m})$. Both cells are rectangular as shown in Fig. 1a with an active surface area of $\approx 70 \mathrm{~cm}^{2}$ and $48 \mathrm{~cm}^{2}$, for Cell$A 1$ and Cell-A2 respectively. Moreover, Cell-A1 is segmented in 20 sectors as depicted in Fig. $1 \mathrm{~b}$ with the external sectors of $3.17 \mathrm{~cm}^{2}$ and the central ones of $3.79 \mathrm{~cm}^{2}$. Although their oxygen electrodes are different, it is worth noting that the cermet of Cell-A1 and Cell-A2 have been

produced by using the same manufacturing protocol and are identical in terms of composition and microstructure.

Cell-B is a circular button cell with an active area of $3.14 \mathrm{~cm}^{2}$ (Fig. 1c). In this case, the hydrogen electrode is a Ni-8YSZ cermet $(\approx 350 \mu \mathrm{m})$ while the electrolyte is made of $8 \mathrm{YSZ}(\approx$ $10 \mu \mathrm{m})$. The oxygen electrode is a single layer of porous LSCF with a thickness of $\approx 50 \mu \mathrm{m}$.

Finally, it can be noticed that, for all the tested cells (Cell-A and Cell-B), a barrier layer of GDC $(\approx 3-5 \mu \mathrm{m})$ is added between the oxygen electrode and the electrolyte in order to limit their reactivity.

\section{Durability Test}

The segmented cell (Cell-A1) was aged for 15000 hours in fuel cell mode at an operating temperature of $780^{\circ} \mathrm{C}$. A nominal flowrate of $\approx 7 \mathrm{Nml.cm}{ }^{-2} \cdot \mathrm{min}^{-1}$ composed of diluted hydrogen was used to supply the fuel electrode $\left(60 \% \mathrm{H}_{2}-40 \% \mathrm{~N}_{2}\right)$, while ambient air was sent to the oxygen electrode (flowrate: $\approx 110 \mathrm{Nml} \cdot \mathrm{cm}^{-2} \cdot \mathrm{min}^{-1}$ ). During the durability experiment, the cell was kept at the Open Circuit Voltage (OCV) or operated in potentiostatic mode. The test was conducted in a specific setup developed by SOLIDpower S.p.A. with a longitudinal co-flow configuration (Fig 1a and 1b) similar to the one reported in [47]. In this setup, the different sectors of the oxygen electrode have been connected to a metallic plate presenting the same segmentation. The insulation between the different metallic sectors has been obtained using a non-conductive glue to avoid their electrical contact. In this way, the local voltages and current densities for each sector of Cell-Al have been measured independently and their 
evolution has been recorded. In this work, we focused our analysis on three samples coming from the inlet, the center and the outlet of the cell as reported in Fig. 1b. For these three segments, the evolution of current densities and voltages during the aging test are shown in Fig. 2. As expected, a higher current density is measured at the inlet of the cell, related to the higher concentration of reactants. Moreover, the evolution of the local voltages during the experiment is quite limited indicating a good stability of the cell. The degradation was also measured analyzing the evolution of global Area Specific Resistance (ASR) at a current density of $\approx 0.25 \mathrm{~A} . \mathrm{cm}^{-2}$. An increase of $\approx 130 \mathrm{~m} \Omega . \mathrm{cm}^{2}$ was measured corresponding to a degradation rate of $\approx 3 \mathrm{mV} \cdot \mathrm{kh}^{-1}$. This rather low value obtained for an operating time of 15000 hours in good agreement with the typical degradation rates measured on classical SOCs over shorter aging periods [10]. This good durability behavior of Cell-Al means that its electrodes microstructures must be stable upon operation, especially for the Ni-YSZ cermet.

The other cells of type $A$ (Cell-A2) were aged in electrolysis mode for 10700 hours in a short stack configuration containing six repeating units (RU). All the details of the stack aging, as well as the data analyses have been already published in [38]. The gas composition at the hydrogen electrode inlet was $90 \% \mathrm{H}_{2} \mathrm{O}$ and $10 \% \mathrm{H}_{2}$, while the oxygen electrode compartment was swept under ambient air (flowrate at the fuel electrode: $\approx 10 \mathrm{Nml} \cdot \mathrm{cm}^{-2} \cdot \mathrm{min}^{-1}$ - flowrate at the oxygen electrode: $\left.\approx 15 \mathrm{Nml} \cdot \mathrm{cm}^{-2} \cdot \mathrm{min}^{-1}\right)$. The cells in the stack were maintained at a temperature ranging between $710^{\circ} \mathrm{C}$ and $730^{\circ} \mathrm{C}$ and were operated in galvanostatic mode at $0.6 \mathrm{~A} . \mathrm{cm}^{-2}$ for the first 3250 hours and at $-0.5 \mathrm{~A} . \mathrm{cm}^{-2}$ up to $\approx 10000$ hours. As for Cell-A1, a limited voltage increase of $0.5 \% \mathrm{kh}^{-1}$ is reported during the test, which corresponds to a degradation rate $\approx 6 \mathrm{mV} \cdot \mathrm{kh}^{-1}$.

The second type of cell investigated in this study $(C e l l-B)$ was also aged in electrolysis mode at $800^{\circ} \mathrm{C}$ for a total time of 1000 hours. The durability experiment was performed at a current density of $-0.5 \mathrm{~A} \cdot \mathrm{cm}^{-2}$. The hydrogen electrode was fed with the same gas composition as CellA2 $\left(90 \% \mathrm{H}_{2} \mathrm{O}-10 \% \mathrm{H}_{2}\right)$ with a total flowrate of $\approx 24 \mathrm{Nml} . \mathrm{cm}^{-2} \cdot \mathrm{min}^{-1}$. Ambient air was sent at the oxygen electrode with a flow rate of $\approx 112 \mathrm{Nml} . \mathrm{cm}^{-2} \cdot \mathrm{min}^{-1}$. The degradation curve and the initial and final performances of the cell are reported in Fig. $3 \mathrm{a}$ and $3 \mathrm{~b}$, respectively. In contrast to Cell-A, a very high degradation rate of $\approx 100 \mathrm{mV} \cdot \mathrm{kh}^{-1}$ was measured in this case.

In order to investigate this striking difference in durability behavior between Cell-A and Cell-B, the Ni-YSZ electrodes for the aged and pristine cells have been reconstructed by

synchrotron X-ray holotomography. The microstructural properties extracted from the volumes have been then implemented an in-house model for analysis.

\section{D Reconstruction Procedure and Description of the Electrochemical Model}

\section{$3 D$ Reconstruction}

For the tomographic experiments, specific specimens in the shape of micro-pillars have been extracted from the pristine and aged cells. These specimens have been prepared using a plasmafocused ion beam (pFIB) Vion (FEI ${ }^{\mathrm{TM}}$ ), in which Xenon ions are used to mill the material $[48,49]$. Using $\mathrm{Xe}^{+}$ions, this technology allows reaching high currents so that the milling rates 
are about 60 times faster than classical $\mathrm{Ga}^{+}$FIB [50]. Thanks to this feature, it is possible to prepare larger samples while keeping a sufficient precision at low currents [51]. The detailed procedure for sample preparation is reported in [50]. In this study, micro-pillars with a diameter of $\approx 50 \mu \mathrm{m}$ have been taken from the cells. As displayed in Fig. 4a for one case, each specimen contains a part of the hydrogen electrode, the electrolyte and the oxygen electrode.

Eight micro-pillars have been analyzed in this work. For Cell-A1, three samples have been extracted from the inlet, the center and the outlet segments as reported in Fig. 1b (named CellA1 Inlet, Cell-A1 Center and Cell-A1 Outlet, respectively). For Cell-A2, one sample coming from the inlet of the fifth RU has been analyzed (Cell-A2 Inlet). Moreover, two samples taken from Cell-B have been studied (Fig. 1c). One of these two samples has been extracted from the center of the cell, in the electrochemically active region (Cell-B Active). The other one has been taken from the periphery of the cell, from a region in which no electrochemistry occurs $(\mathrm{Cell}-$ $B$ Inactive). Finally, for both types of cell, a representative reference sample coming from a pristine cell just after the cermet reduction has also been prepared and reconstructed ( $\mathrm{Cell}-\mathrm{A}$ Reference and Cell-B Reference).

The cermet microstructures have been reconstructed by synchrotron X-ray nanoholotomography carried out at the Nano-Imaging beamline (ID16A) of the European Synchrotron Radiation Facility (ESRF). In this technique, the sample is illuminated by using a coherent X-ray beam with high photon flux. The refractive index of the materials, which is related to the local electron density in the sample, induces a change in the wavelength resulting in a phase shift at the outlet of the specimen. This phase shift contains the microstructural information used to reconstruct the electrode. By analyzing this phase modification, it has been shown that the distinction between the pores, the nickel and the YSZ inside the reconstructed cermet is possible [52]. It is worth mentioning that all the procedure including the selection of the photons energy $(33.6 \mathrm{keV})$, the data acquisition and the algorithm of reconstructions have been optimized for the characterization of SOCs materials [53,54]. Thanks to this optimization, 3D image of the electrode microstructure are obtained with a large field of view (reconstructed volume of $\left.\approx 50.2 \times 25.6^{2} \times \pi \mu \mathrm{m}^{3}\right)$ and high spatial resolution $(\approx 50 \mathrm{~nm}$ with a voxel size of 25 $\mathrm{nm})$ [50]. These features are of critical importance to be representative of the SOC microstructure but also to observe the long distance redistribution of nickel in the cermet.

Once the microstructure had been reconstructed, a region containing part of the hydrogen electrode and the electrode/electrolyte interface has been identified. For each sample, a subvolume of $\approx 30 \times 30 \times 30 \mu \mathrm{m}^{3}$ has been selected and the raw images have been processed by using in-house codes in order to identify the percolated phases (Ni, pores and YSZ) $[52,55,56]$. For this purpose, the raw data in grey levels have been filtered following the approach proposed by [57] to enhance the contrast between the different phases. Afterwards, the filtered 3D images have been segmented using the criterion proposed by [58], and a specific value has been assigned to each phase. A visual comparison between a $2 \mathrm{D}$ cross-section taken from the raw $3 \mathrm{D}$ image and the corresponding $2 \mathrm{D}$ slice coming from the segmented reconstruction is shown in Fig. 4b. A good accordance can be noticed between the two images proving the reliability of the filtering and segmentation procedures. A 3D rendering volume containing a part of the $\mathrm{Ni}-\mathrm{YSZ}$ and a part of the electrolyte is also given in Fig. $4 \mathrm{c}$ as an illustration. As a last step, 
the connected paths for each phase have been identified in the reconstructions [56] so that the microstructural properties are computed on the percolated and disconnected phases.

The density of active TPBls ( $\left.\xi_{\text {TPBls }}\right)$, the volume fraction of each phase (Vf), the specific surface areas $\left(\mathrm{Sp}_{\mathrm{i}-\mathrm{j}}\right)$ and the mean phase diameters $\left(\overline{\mathrm{D}}_{\mathrm{m}}\right)$ have been measured on the volumes using in-house algorithms [59]. Moreover, the M-factors, defined as the ratio between the effective conductivity (or diffusivity) and the intrinsic value for the solid (or gas) phase, have been computed by solving the Laplace equation on the microstructures [54]:

$$
M-\text { factor }_{i}=\frac{\sigma_{i}^{\text {eff }}}{\sigma_{i}^{\text {bulk }}}
$$

Where $\sigma_{\dot{i}}^{\text {eff }}$ and $\sigma_{i}^{\text {bulk }}$ represent the effective and the intrinsic conductivity/diffusivity of phase i.

All these microstructural parameters have been computed in two ways: (i) to evaluate the global microstructural evolution in the bulk and (ii) to take into account the potential gradients arising in the neighborhood of the electrode/electrolyte interface. For this purpose, the microstructural properties in the bulk of the electrodes have been calculated for each reconstruction on a sub-volume taken at $\approx 10 \mu \mathrm{m}$ away from the electrode/electrolyte interface $\left(\approx 30 \times 30 \times 20 \mu \mathrm{m}^{3}\right)$ (Fig. $4 \mathrm{c}$ ). In order to evaluate the gradients, the firsts $10 \mu \mathrm{m}$ of each NiYSZ electrode reconstruction have been divided in slices of $30 \times 30 \times 0.5 \mu \mathrm{m}^{3}$ (Fig. $4 \mathrm{~d}$ ) and the local microstructural parameters have been calculated with a slice-by-slice approach.

\section{Electrochemical Models Presentation}

The microstructural data of the different samples have been introduced in an in-house developed multiscale model to compute the cell degradation after aging. This modeling framework combines the detailed reaction mechanisms at the electrode/electrolyte interface to the global cell performances. For this purpose, two microscale 1D models describing the reaction pathways at the oxygen and hydrogen electrodes are coupled to a macroscopic $2 \mathrm{D}$ model describing the overall cell response. It is worth mentioning that a thorough presentation of the electrodes and cell models can be found in $[7,44-46,50,60]$, while a description of their interactions has been already detailed in $[44,61]$. Since the present study is focused on the cermet response, a short description of the hydrogen electrode model is reported hereafter by highlighting the specific adaptations considered for this work.

This model considers a slice of Ni-YSZ active layer taking into account the detailed kinetics occurring therein. The model is based on the hydrogen spillover mechanism reported as the most classical reaction pathway for the Ni-YSZ cermet $[33,34,62,63]$. The overall reaction mechanism is depicted in Fig. 5a, and the reactions considered in the model are reported in Table I. Their associated kinetic rates are expressed as simple chemical reactions except for the charge transfers ( $\mathrm{ct}_{1}$ and $\mathrm{ct}_{2}$ ) for which the classical Butler-Volmer formalism has been used (Table I). For all the reactions, the forwards and backwards kinetic constants have been linked via their thermodynamic equilibrium constants. In order to express the activities of the species adsorbed on the YSZ, it can be noticed that the water molecules and the hydroxyl ions have been assumed to be attached only on the $\mathrm{Zr}$ sites at the YSZ surface $\left(\mathrm{s}_{\mathrm{Zr}}\right)$ [33,64]. Moreover, 
the incorporation into the lattice of the oxygen ions adsorbed on the oxygen vacancies surface sites $\left(\mathrm{s}_{\mathrm{V}_{\mathrm{O}}}\right)$, has been supposed to be not limiting.

In this work, specific attention has been paid to take into account the real microstructural data of the Ni-YSZ cermet computed on the 3D reconstructions. In that objective, the gradients of properties evaluated using the slice-by-slice approach have been introduced to express the local kinetic rates, the effective gas diffusivities and the electronic/ionic effective conductivities evolving from the electrolyte interface towards the bulk of the electrode. For this purpose, the local kinetic rates for the surface reactions have been scaled by the local Ni/gas or YSZ/gas interfacial specific surface areas whereas the kinetics for the charge transfer reactions are proportional to the local density of active TPBs (Table I). It is also reminded that the $\mathrm{M}$-factors used to compute the local effective diffusivities and conductivities can be related to the ratio between the phase volume fraction and the tortuosity factor [65].

Finally, the electrode response is simulated by solving the set of partial differential equations related to the mass and charge balances for all the considered species [46]. It is worth noting that a transient term is considered in these conservation equations to simulate the dynamic response of the electrode and to investigate the evolution of Electrochemical Impedance Spectroscopy (EIS) diagrams after degradation.

The model validity has been checked in this study by comparing the simulated and the experimental polarization curves for Cell- $A$ (Fig. 5b). The i-V curves have been obtained at $750^{\circ} \mathrm{C}$ and $850^{\circ} \mathrm{C}$ in electrolysis mode with an inlet gas flux composed of $90 \% \mathrm{H}_{2} \mathrm{O}$ and $10 \%$ $\mathrm{H}_{2}$ for the hydrogen electrode (total flow rate of $12 \mathrm{Nml} . \mathrm{cm}^{-2} \cdot \mathrm{min}^{-1}$ ) and dry air for the oxygen electrode (flow rate of $62 \mathrm{Nml} \cdot \mathrm{cm}^{-2} \cdot \mathrm{min}^{-1}$, respectively). As shown Fig. 5b, a very good agreement is found between the simulated curves and the experimental data. This result highlights the model ability to reproduce accurately the cell performances. Therefore, this model can be considered validated for this study and it can be used to evaluate the impact of $\mathrm{Ni}$ agglomeration/redistribution on the SOC response.

\section{Results of the Microstructural Analysis}

\section{Microstructural Properties of the Reference Cells}

As a first analysis, the reconstructions coming from the two reference samples (Cell- $A$ Reference and Cell-B Reference) have been studied to investigate the differences in the initial microstructures between the two types of Ni-YSZ electrodes.

The comparison between the two rendering volumes taken in the bulk of the two pristine cermets is shown in Fig.6a and 6b. It can be seen that the two initial microstructures differ significantly between each other. On the one hand, Cell-A Reference presents a fine microstructure with a rather homogenous distribution of Ni particles (Fig. 6a). On the other hand, Cell-B Reference presents a much coarser microstructure, with large agglomerates of $\mathrm{Ni}$ even before aging (Fig. 6b). This difference in the initial microstructures is also revealed by the inspection of the nickel particle size distribution (PSD) plotted for the two electrodes (Fig. 
6c). The coarser microstructure for Cell-B Reference is reflected in a broader distribution for the Ni phase compared to the narrow peak computed for Cell-A Reference. As a result, the Ni mean particle diameter of Cell-B Reference is more than twice the one for Cell-A $(1.14 \mu \mathrm{m}$ vs $0.46 \mu \mathrm{m}$ : cf. Fig. 6c). From this observation, an important difference in the other microstructural parameters for the two samples can be expected. Indeed, a finer microstructure must lead to a higher number of active TPBls and higher $\mathrm{Sp}_{\mathrm{i}-\mathrm{j}}$ between the phases [66]. This dependence is well confirmed by the microstructural properties provided in Table II for the two types of cermet.

Finally, the local Ni volume fractions for the two pristine cells are plotted in Fig. $6 \mathrm{~d}$ as a function of the position in the depth of the cermet starting from the electrolyte interface (i.e. $z=0$ in Fig. $6 d$ ). In both cases, gradients with a quite sharp increase of the Ni volume fraction are detected. Because of its coarser microstructure, the transition for Cell-B is smoother and more extended before reaching the Ni volume fraction in the bulk. These gradients, which are observed even for the pristine cermet, can probably be explained by the manufacturing process based on the co-sintering of the electrolyte and the cermet. To investigate the morphological evolution of $\mathrm{Ni}$ after operation for the two types of cell, the reconstructions coming from the aged samples have been analyzed.

\section{Microstructural Evolution of the Aged Cells}

Evolution in the Bulk - Fig. 7 displays the 3D rendering volumes as well as the 2D images extracted from the bulk of the aged samples. For Cell-A1, only the reconstruction coming from the outlet (Cell-Al Outlet) is shown as an illustration of the overall microstructural evolution for this cell. The visual comparison between Fig. 6 and Fig. 7 shows without any ambiguity that all cermets are subjected to an agglomeration of nickel after aging. Nevertheless, it is clear that the morphological evolution is more pronounced for Cell- $B$ than for Cell- $A$.

To deepen the analysis, all the microstructural parameters measured on the $3 \mathrm{D}$ volumes after operation have been computed and are given in Table II. The evolution of the properties between the fresh and the aged cells confirms the Ni agglomeration arising upon operation. Indeed, an increase of the mean $\mathrm{Ni}$ diameter is found in all the reconstructions taken from the operated cells. As expected, the Ni particle coarsening is accompanied by a loss of TPBls densities and by a decrease in the specific surface area of Ni (Table II).

It can be noticed that, for the aged specimens of Cell- $A$, the $\mathrm{Ni}$ volume fractions remain almost constant after aging. This behavior confirms that the agglomeration in the bulk can be described by a local particle sintering without significant redistribution of $\mathrm{Ni}$ at long-distance. Furthermore, the Ni particle growth is not severely influenced by the polarization nor the gas composition, in good agreement with the thermally activated process related to Ni coarsening proposed in [18]. This behavior is in accordance with the experimental results reported by [67].

Conversely, for Cell-B, a noticeable enrichment of $\mathrm{Ni}$ is measured in the bulk of the cermet after operation. This behavior is more pronounced in the sample taken from the electrochemically active region (Cell-B Active) than in the sample extracted from the periphery 
of the cell (Cell-B Inactive). This type of evolution could be explained by a combination of $\mathrm{Ni}$ agglomeration based on local sintering and Ni volatilization/re-deposition process [30].

To investigate the $\mathrm{Ni}$ evolution at the electrode/electrolyte interface the local microstructural properties of the aged cells have been calculated using the slice-by-slice approach.

Evolution at the Electrode/Electrolyte Interface - In Fig. 8, a zoom on the cermet microstructure at the electrode/electrolyte interface for each reconstruction is shown. To better visualize the microstructural evolutions, 2D images coming from the whole reconstructions are shown with slices taken perpendicular and parallel to the interface with the electrolyte. Once again, for Cell-Al only the outlet reconstruction (Cell-A1 Outlet) is reported as an illustration.

As shown in Fig. 8a, 8b and 8c for Cell-A, nickel is present at the electrode/electrolyte interface for the reference cell as well as for all the aged samples. Nevertheless, it can be noticed that the sample operated for 10700 hours in electrolysis mode (Cell-A2 Inlet, Fig. 8c) presents a slight depletion of $\mathrm{Ni}$ at the interface that is not observed in the sample aged for 15000 hours in fuel cell mode even at high steam partial pressure (Cell-A1 Outlet, Fig. 8b).

On the contrary, the local evolutions for Cell-B are quite different as can be seen in Fig. 8d, $8 \mathrm{e}$ and $8 \mathrm{f}$. In this case, after only 1000 hours in electrolysis mode, a severe Ni depletion is observed at the electrode/electrolyte interface for the sample coming from the electrochemically active region (Cell-B Active, Fig. 8e). This evolution is in good agreement with the enrichment that has been measured in the bulk of the sample. However, it is worth noting that a larger amount of $\mathrm{Ni}$ is still present at the interface for the sample extracted from the periphery of the aged cell (Cell-B Inactive, Fig. 8f). These results reveal that an important loss of nickel from the electrode/electrolyte interface occurs for this type of cell, specifically in the electrochemical active region.

To confirm these evolutions, the gradients in the local microstructural parameters have been evaluated at the electrode/electrolyte interface using the slice-by-slice approach (Fig. 9).

For Cell-A1, the gradients for the inlet, center and outlet reconstructions are almost superimposed with only a minor decrease of $\mathrm{Ni}$ volume fraction for the outlet segment (Fig. 9a). This slight evolution could be associated to the higher steam partial pressure at the outlet of this cell operated in SOFC mode. However, it is worth mentioning that the difference is very limited even after 15000 hours, indicating an overall similar evolution between the three segments.

Conversely, a more-pronounced decrease of Ni volume fraction is found for Cell-A2, which is concomitant with an increase of the pore volume fraction (Fig. 9c). This slight Ni depletion extends from the electrolyte interface in the two first micrometers within the cermet. It can be noticed that this extension is in good agreement with the observations reported in [38], where cells coming from the same stack have been characterized. This Ni depletion induces a moderate loss of TPBls and Ni specific surface area as shown in (Fig. 9e and 9g). From this analysis of $C e l l-A$, it can be stated that the $\mathrm{Ni}$ depletion is favored under cathodic polarization (i.e. electrolysis mode) although it is worth mentioning that this phenomenon is rather limited for both cells (Cell-A1 and Cell-A2). 
In contrast to Cell- $A$, the severe Ni depletion at the electrode/electrolyte interface for Cell$B$ Active is confirmed by the local quantifications of the Ni volume fractions. Indeed, an important loss of $\mathrm{Ni}$ is measured at the electrolyte interface, which spreads in the first $\approx 5-6$ $\mu \mathrm{m}$ of the electrode (Fig. 9b). This local decrease of Ni volume fraction is accompanied by a simultaneous increase of the porosity (Fig. 9d). Therefore, a quite full depletion of $\mathrm{Ni}$ is measured nearby the electrolyte interface in good agreement with the 2D slice given in Fig. 8e. Consequently, a huge decrease of $\xi_{\mathrm{TPBls}}$ and $\mathrm{Sp}_{\mathrm{Ni}}$ is measured at the interface (Fig. $9 \mathrm{f}$ and $9 \mathrm{~h}$ ) for this sample. On the contrary, the local evolution for Cell-B Inactive are more similar to the pristine cermet, reinforcing the observation that no severe migration of nickel is detected in this sample. This statement is in good agreement with the experimental observation reported in $[31,37]$, indicating the key impact of the electrochemical activity on the Ni depletion.

Finally, from the comparison between the behavior of Cell-A and Cell-B, it can be pointed out that the initial microstructure of the electrode and the nature of the materials of the Ni-YSZ cermet play a central role on the severity of the loss of $\mathrm{Ni}$ from the electrode/electrolyte interface.

\section{Discussion}

\section{Impact of Ni Evolution on the Cell Performances}

Role of Ni Agglomeration on Degradation - To investigate the impact of Ni agglomeration, our dataset for Cell-A has been merged with the one analyzed in [18] for the same type of cell. In Fig. 10a, the evolutions at different temperatures of the $\mathrm{Ni}$ mean particle diameters are plotted as a function of the operating time. It can be noticed that the data for Cell-Al and Cell$A 2$ are roughly aligned with those of the sample aged at $750^{\circ} \mathrm{C}$ for 9000 hours in fuel cell mode taken from [18]. For this reason, these data have been fitted approximating the aging temperature at $750^{\circ} \mathrm{C}$ and using the phenomenological agglomeration law based on an Ostwald ripening process proposed in [18]:

$$
\left[\overline{\mathrm{D}}_{\mathrm{m}}(\mathrm{t})^{\mathrm{n}}-\overline{\mathrm{D}}_{\mathrm{m}}(\mathrm{t}=0)^{\mathrm{n}}\right]=\mathrm{k}_{\text {pow }} \times \mathrm{t} \quad \text { with } \quad \mathrm{k}_{\mathrm{pow}}=\mathrm{k}_{00} \times \exp (-\Delta \mathrm{H} / \mathrm{RT})
$$

Where $\mathrm{t}, \mathrm{n}$ and $\Delta \mathrm{H}$ represent the time, the process related exponent and the activation energy.

As can be seen from Fig. 10a, the data are accurately fitted using $\mathrm{n}=8$ and an activation energy of $\approx 210 \mathrm{~kJ}^{\mathrm{mol}}{ }^{-1}$. This high exponent confirms the inhibiting effect of the YSZ backbone that limits the rate of $\mathrm{Ni}$ agglomeration in the cermet [18,23,36]. This statement is also highlighted by the relative stability of SpYSZ-Ni with respect to the $\mathrm{Sp}_{\mathrm{p}-\mathrm{Ni}}$, as reported in Table II for the aged cells of type $A$. Conversely, the evolutions of the specific surface areas are quite different for Cell- $B$ with a higher modification of SpYsZ-Ni under operation (Table II). This difference between the two types of cells is in good agreement with the more severe $\mathrm{Ni}$ coarsening of Cell-B and reveals the crucial role of the Ni/YSZ interfacial adhesion on the electrode microstructure stability. 
To determine the decrease of TPBls density associated to the Ni agglomeration as function of the aging time, eq. (2) has been combined with the microstructural correlation given in [66]. As shown in Fig. 10b, a satisfactory approximation of the TPBls decrease at $850^{\circ} \mathrm{C}$ and $750^{\circ} \mathrm{C}$ is found without any additional fitting.

The TPBls evolutions at the two temperatures have been implemented in the multi-scale model to quantify the impact of Ni agglomeration on the cell degradation. For the different values of $\xi_{\text {TPBls, }}$, the cell response has been evaluated at $750^{\circ} \mathrm{C}$ and $-0.5 \mathrm{~A} . \mathrm{cm}^{-2}$. The gas compositions used for the simulations were $90 \% \mathrm{H}_{2} \mathrm{O}-10 \% \mathrm{H}_{2}$ at the hydrogen electrode (flowrate of $12 \mathrm{Nml} \cdot \mathrm{cm}^{-2} \cdot \mathrm{min}^{-1}$ ) and air at the oxygen electrode (flowrate of 62 $\left.\mathrm{Nml} . \mathrm{cm}^{-2} \cdot \mathrm{min}^{-1}\right)$. Taking advantage of the model calibration over long operating times, the voltage increase has been calculated up to 20000 hours. It is shown in Fig. 10c that the Ni agglomeration tends to stabilize for very long-term operation. For instance at $750^{\circ} \mathrm{C}$, the voltage degradation evolves from $\approx 5 \mathrm{mV}$ at 8000 hours to $\approx 8 \mathrm{mV}$ at 20000 hours. Therefore, even if there is not a full asymptotic behavior for the $\mathrm{Ni}$ coarsening, its impact on the performance does not diverge and should not compromise the cell durability on its overall requested lifetime $(\approx 40000$ hours $)$.

Role of Ni Depletion on Degradation - In addition to the agglomeration, the depletion of $\mathrm{Ni}$ from the electrolyte interface is also expected to decrease the cell performance. Although a general physically-based model describing the Ni migration is still missing, the gradients measured on the two types of studied cells (Cell-A2 Inlet and Cell-B Active) can be used as lower and upper bounds to evaluate the impact of loss of nickel. To quantify the cell degradation in these two limiting cases, the corresponding microstructural evolutions at the electrode/electrolyte interface have been implemented in the model. The hydrogen electrode overpotential and the cell performances have been simulated after 11000 hours at $750^{\circ} \mathrm{C}$ (Fig $10 \mathrm{~d}$ and $10 \mathrm{e})$. In case of moderate depletion, it is found that the effects on the electrode and cell responses are quite limited. Indeed, in this case a voltage loss of $\approx 6.5 \mathrm{mV}$ can be assessed at $\mathrm{i}=-0.5 \mathrm{~A} \cdot \mathrm{cm}^{-2}$ for the complete cell. This value is slightly above to the degradation computed by considering only the agglomeration for the same aging conditions $(\approx 5.5 \mathrm{mV})$. This result indicates that, in this case, the degradation in cell performances due to the microstructure change in the hydrogen electrode is mainly controlled by the Ni agglomeration while the impact of Ni migration is noticeable but not dominant.

On the contrary, when a severe loss of $\mathrm{Ni}$ from the electrode/electrolyte interface is introduced in the model (with the gradients for Cell-B Active), the effects on the electrode and cell response are much more pronounced (Fig. 10d and 10e). In this case, the increase of the absolute value for the electrode overpotential is much higher than if only the agglomeration is taken into account. This huge electrode degradation yields to a significant cell voltage loss of $\approx 50 \mathrm{mV}$ calculated at $-0.5 \mathrm{~A} \cdot \mathrm{cm}^{-2}$. A sensitivity analysis has been conducted with the model to identify the most impacting microstructural parameters. It has been found that the important cell degradation is mainly related to the substantial loss in the local density of TPBls at the electrolyte interface that directly controls the rate of the charge transfer reactions. In the same time, the effect of the other microstructural changes has been found to be less impacting. Indeed, even with the significant decrease of the Ni volume fraction, the local effective $\mathrm{Ni}$ conductivity in the active layer remains sufficiently high to not induce too large ohmic losses. 
Moreover, in our case, it has been found that the decrease of the Ni/gas interfacial surface area does not influence the electrode/cell performances as the reactions taking place at the Ni surface are not limiting [68].

This high impact of the Ni depletion on the charge transfer reactions is also confirmed by the EIS spectra computed at OCV for the hydrogen electrode in the two limiting situations of Ni migration (Fig. 10f). In case of moderate loss of Ni from the electrode/electrolyte interface, an overall limited increase in the polarization resistance is obtained for the aged electrode, while the characteristic frequencies remain comparable to the reference. Instead, when a severe depletion is considered, an important increase of the polarization resistance is calculated. This higher resistance is accompanied by an increase of the contribution of the high frequency phenomenon, which is classically associated with the charge transfer at the TPBls [69]. In our case, it is worth noting that $\mathrm{Ni}$ is still percolating up to the interface with the electrolyte even considering the severe gradients taken for Cell-B Active. In this condition, the serial resistance of the EIS diagrams is not shifted due to an additional ohmic resistance induced by a fully depleted layer in $\mathrm{Ni}$.

From these numerical analyses, it appears that the impact of the Ni depletion on the cell performances can be very important depending on the initial cermet microstructure. This statement must explain a large part of the higher experimental degradation rates measured for the Cell $B$ compared to Cell $A$. Moreover, it is worth reminding that the destabilization of the oxygen electrode material accelerated under electrolysis current must also contribute to the overall cell degradation $[14,21]$.

Finally, the comparison between the two studied cermet microstructures of Cell-A and Cell$B$ shows that the mitigation of the $\mathrm{Ni}$ depletion should be possible by microstructural

optimization. Nevertheless, in this objective, it is still required to clarify the underlying mechanisms driving the migration.

\section{Mechanism of Ni Depletion}

Based on our experimental results, it can be stated that the Ni migration causes a loss of nickel at the electrolyte interface. This Ni depletion takes place within the cermet active layer where the electrochemical reactions take place. Indeed, a clear influence of the electrochemistry on the severity of the Ni depletion has been detected. Moreover, it appears that this phenomenon is strongly favored in cathodic polarization (i.e. SOEC mode) whereas the analyses of the samples aged in fuel cell mode indicate that the impact of the steam partial pressure remains less pronounced. Finally, the comparison between Cell-A and Cell-B highlights the strong impact on the Ni redistribution of the initial characteristics of the electrode (in terms of microstructure and materials). Indeed, it has been clearly shown that the $\mathrm{Ni}$ migration is favored in case of coarser initial microstructures. Moreover, as for the $\mathrm{Ni}$ agglomeration, it can be suspected that the nature of the Ni/YSZ interface could play a central role in the Ni depletion (i.e. interfacial adhesion between Ni and YSZ).

Even if the precise mechanism for the Ni depletion is not completely understood, it has been proposed that the Ni migration occurs in the gas phase with the formation of volatile hydroxyl species according to [11,32]: 


$$
\mathrm{Ni}+\mathrm{OH}_{\mathrm{Ni}} \rightarrow \mathrm{Ni}(\mathrm{OH})(\text { gas }) \quad \text { or } \quad \mathrm{Ni}+\mathrm{O}_{\mathrm{Ni}}+\mathrm{H}_{2} \mathrm{O}(\text { gas }) \rightarrow \mathrm{Ni}(\mathrm{OH})_{2} \text { (gas) }
$$

Based on these reactions, an influence of the steam partial pressure and the activities of the oxygen and hydroxyl species attached on the Ni surface could be expected. To verify these dependencies, the micromodel for the hydrogen electrode has been used to simulate the electrode behavior at $+/-0.5 \mathrm{~A} \cdot \mathrm{cm}^{-2}$, with a gas composition of $50 \% \mathrm{H}_{2} \mathrm{O}-50 \% \mathrm{H}_{2}$ at $750^{\circ} \mathrm{C}$. The evolution of the steam partial pressure and the coverages of species attached on the surface of $\mathrm{Ni}$ are presented in Fig. 11a, $11 \mathrm{~b}$ and $11 \mathrm{c}$ as function of the position in the electrode. It can be seen that surface concentrations of oxygen and hydroxyl adsorbates are increased in fuel cell mode and decreased in electrolysis mode (Fig. 11b and 11c). According to the gas interaction with $\mathrm{Ni}$ (cf. Table I), these evolutions are consistent with the higher steam partial pressure at the electrolyte interface in fuel cell compared to electrolysis mode (Fig. 11a). Regarding the reactions of Ni evaporation (3), these simulations suggest that the $\mathrm{Ni}(\mathrm{OH})_{\mathrm{x}}$ formation should be promoted under fuel cell current in the electrode active layer. In other words, if the rate-limiting step is the Ni evaporation, the global process should be accelerated in fuel cell mode. However, the analysis of the experimental results has clearly revealed that the depletion of $\mathrm{Ni}$ from the electrode/electrolyte interface is favored in electrolysis mode, while it remains almost negligible in SOFC mode, even at high $\mathrm{p}\left(\mathrm{H}_{2} \mathrm{O}\right)$. This contradictory result indicates that the $\mathrm{Ni}$ evaporation cannot be the limiting step for the Ni depletion. This means that even if the Ni migration occurs via volatile species, there must be another physical phenomenon triggering the nickel instability.

In this context, it has been proposed that the electrode polarization could be involved in the mechanism of Ni depletion [37]. To check this possibility, the local electrode overpotentials have been plotted in the depth of the electrode for a current density of $+/-0.5{\mathrm{~A} . \mathrm{cm}^{-2}}^{-}$(Fig. 12a). In contrast to the coverages and steam partial pressures, a sharp evolution of the electrode overpotential is simulated. These evolutions spread from the electrolyte interface over $\approx 5 \mu \mathrm{m}$ micrometers within the cermet. Interestingly, this penetration depth of the charge transfer reactions is in the same range as the one for which the Ni depletion has been observed in Fig. $9 \mathrm{~b}$. Therefore, the large overpotential difference in anodic and cathodic polarization could be associated to the process of $\mathrm{Ni}$ depletion triggered in electrolysis mode.

In this frame, it has been recently proposed that the driving force for the Ni transport could be a gradient in Ni wettability across the active layer as a function of the electrode overpotential [70,71]. Alternatively, it has been suggested that the reductive potential could induce the detachment of Ni from YSZ [37,72]. Once detached, the Ni particles would no longer be stabilized by the YSZ backbone. These highly unstable particles could evaporate and increase the local partial pressure of hydroxyl species that would diffuse toward the bulk. Besides, the detachment of the Ni from the YSZ would modify the local electrochemical activity, inverting the local steam partial pressure gradients. In this condition, the isolated Ni particles could also evaporate and migrate in the gas phase to agglomerate in the upper layer of the electrode $[31,37]$. It is worth mentioning that a mechanism of Ni depletion controlled by the delamination between Ni and YSZ is in good agreement with the experimental observation. Indeed, it allows taking into account the influence of the Ni/YSZ interfacial stability highlighted by the comparison between Cell-A and Cell-B. As already discussed, this stability could be related to the adhesion of Ni on the YSZ which is strongly dependent on contaminants in YSZ [73-75]. 
It could be also related to the microstructural difference between the two cermets. Indeed, the fine microstructure of Cell-A with a high density of TPBs allows limiting the overpotential for a given current density and could therefore mitigate the process of $\mathrm{Ni}$ migration. To illustrate this possibility, the model has been used and it has been shown that the passage from the coarse to the fine microstructure of $C e l l-B$ and $C e l l-A$ allows reducing significantly the absolute value of the overpotential at the electrolyte interface. For example, at a current of $-0.5 \mathrm{~A} . \mathrm{cm}^{-2}$, a decrease of $\approx 35 \mathrm{mV}$ for the absolute value of the overpotential has been calculated at the electrolyte interface $\left(750^{\circ} \mathrm{C}\right.$ and gas composition $\left.50 \% \mathrm{H}_{2} \mathrm{O}-50 \% \mathrm{H}_{2}\right)$. This quantification is in good agreement with the analysis reported by [41] suggesting that a fine $\mathrm{Ni}$ particle distribution would reduce the depletion of Ni. In addition, it can be noticed that increasing the temperature from $700^{\circ} \mathrm{C}$ to $800^{\circ} \mathrm{C}$ also induces a significant decrease of the electrode overpotential. From this point of view, a higher operating temperature should alleviate the rate of Ni depletion.

In spite of all these results, the exact microscopic process at the origin of the nickel instability at the electrode/electrolyte interface remains unclear. As an explanation, it could be proposed that the high cathodic overpotential could modify the structure of the double layer leading to the deterioration of the Ni/YSZ interface. In other words, the polarization could affect the Ni/YSZ interfacial adhesion through the accumulation of charges in the double layer. Indeed, the atomic interaction between the $\mathrm{Ni}$ and $\mathrm{YSZ}$ is characterized by a large number of $\mathrm{Ni}-\mathrm{O}$ bonds at the interface [76,77]. From this statement, it was suggested by Sasaki et al. [76] that 'the number of on-top Ni-O bonds is one of the critical factors that can determine the stability of the metal/oxide interface'. Therefore, the replacement of $\mathrm{O}$ atoms by vacancies (due to a modification of the double layer structure in electrolysis mode) is expected to reduce the number of Ni-O bonds, and hence, to weaken the Ni-YSZ adhesion.

To assess the relevance of this suggestion, the concentration of oxygen vacancies in the vicinity of the electrolyte interface has been evaluated as a function the electrode polarization. In the bulk of the solid phases, that is to say far away from the TPBs lines, the Ni/YSZ interface can be seen as a blocking electrode. In this case, the oxygen vacancies concentration could be modeled considering a classical Boltzmann distribution, with a maximal concentration depending on the material [78]:

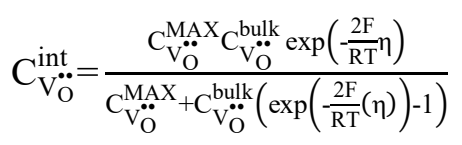

Where $\eta$ is the electrode overpotential, $\mathrm{C}_{\mathrm{V}_{\mathrm{O}}^{*}}^{\mathrm{int}}$ is the oxygen vacancies concentration taken at the $\mathrm{Ni} / \mathrm{YSZ}$ interface and $\mathrm{C}_{\mathrm{V}_{\mathrm{O}}^{\circ}}^{\mathrm{MAX}}$ is the maximum concentration of vacancies in YSZ. The term $\mathrm{C}_{\mathrm{V}_{\mathrm{O}}^{\circ}}^{\text {bulk }}$ denotes the bulk concentration of vacancies. By coupling eq. (4) with the electrochemical model, the evolution of the oxygen vacancies at the electrolyte interface has been plotted as a function of the current density. In Fig. 12b, a sharp increase of oxygen vacancies can be observed at the electrolyte interface with increasing cathodic current in SOEC mode. It can be noticed that this evolution is steeper for a coarser microstructure due to the 
higher negative overpotential for a given current density. Conversely, the decrease of vacancies is less pronounced under anodic polarization in SOFC mode. The strong accumulation of vacancies in the double layer associated to a depletion of oxygen could thus trigger the destabilization of the interface leading to the Ni/YSZ delamination (Fig 12c). Interestingly, interfacial cracks between $\mathrm{Ni}$ and YSZ have been observed in the active layer after aging in electrolysis mode [41,72].

Finally, it can be noticed that the weakening of the Ni/YSZ interface due the accumulation of oxygen vacancies could lead to the detachment of $\mathrm{Ni}$ and trigger the migration of the highly unstable isolated particles via volatile species. Moreover, the decrease of the Ni-YSZ interfacial energy will increase the Ni wettability in the vicinity of the electrolyte interface. This evolution has been measured by Rinaldi et al. [71] after aging in electrolysis mode and could also be involved in the process of Ni migration. From this point of view, increasing the interfacial adhesion between $\mathrm{Ni}$ and YSZ could represent the main challenge to mitigate the $\mathrm{Ni}$ depletion in electrolysis mode. Nevertheless, further investigations are still required for a full validation of this proposition.

\section{Conclusions}

In this work, two classical solid oxide cells with different Ni-YSZ microstructures have been aged in fuel cell and electrolysis modes for operating times ranging from 1000 hours to 15000 hours. In electrolysis mode, it has been found that the degradation is much higher for the cell that presents a coarser Ni-YSZ microstructure. To analyze this result, the hydrogen electrodes of the pristine and aged cells have been reconstructed by synchrotron X-ray holotomography. Thanks to the large volume of the 3D images, the Ni-YSZ microstructural evolutions have been investigated in the bulk and at the electrode/electrolyte interface.

The quantification of the microstructural properties in the bulk has revealed a Ni particle growth for all the operated samples. This phenomenon of agglomeration is independent of the polarization and it can be ascribed to a local sintering process. The comparison between the two cells has confirmed the crucial role of the Ni/YSZ interfacial adhesion on this mechanism.

The microstructural evolutions have been introduced in a multi-scale model to quantify the impact of the Ni agglomeration on the electrode and cell performances. Thanks to the data extracted from the longest experimental dataset, the effects of the Ni agglomeration have been extrapolated up to 20000 hours with a good level of confidence. As expected, the contribution of the agglomeration on the cell degradation is significant but tends to slow down for very long-term operation. From this point of view, it should not compromise the cell durability on its overall requested lifetime.

The analyses of the 3D electrode reconstructions have also revealed a Ni migration toward the bulk of the electrodes resulting in Ni depletion at the electrode/electrolyte interfaces. It has been found that this Ni migration is favored in electrolysis mode and much less pronounced in fuel cell operation. Moreover, the phenomenon has been observed to occur only in the electrochemically active region of the hydrogen electrode. The microstructural characterization

of the two cells has highlighted the strong impact of the initial characteristics of the electrode. 
Indeed, it has been clearly stated that the Ni depletion is favored in case of coarser initial microstructure.

As for the agglomeration, the gradients in microstructure parameters due to the loss of $\mathrm{Ni}$ at the electrode/electrolyte interface have been implemented in the model. In electrolysis mode, the impact of the moderate $\mathrm{Ni}$ depletion observed for the fine electrode microstructure is limited in such a way that the electrode degradation remains dominated by the agglomeration. Conversely, for the coarse cermet microstructure, the severe depletion induces a strong decrease of the cell and electrode performances. This behavior must explain a large part of the difference in the experimental degradation rates measured for the two types of cells. A sensitivity analysis performed with the model has shown that the important loss of active TPBls at the electrolyte interface is the main cause of the degradation whereas the evolutions of the other parameters is less impacting. The effect of the Ni depletion on the impedance spectra has been also computed and discussed.

Finally, the underlying mechanism at the origin of the Ni migration has been discussed taking advantage of the model. The simulations at the electrode scale have shown that the reaction of $\mathrm{Ni}$ evaporation cannot be the limiting step in the depletion process. Instead, the computation of the local overpotential at the electrode/electrolyte interface has revealed a large difference between the two operating modes. In this frame, the high cathodic overpotential under electrolysis current could be involved in the rate of Ni depletion. In order to unravel the role of the overpotential on Ni redistribution, the concentration of oxygen vacancies in the double layer has been estimated at the electrolyte interface in both operating modes. A strong accumulation of vacancies at high cathodic overpotential has been found. It has been proposed that this accumulation could deteriorate the Ni/YSZ interface leading to detach the Ni particles and favor the loss of nickel from the electrode/electrolyte interface. This mechanism allows taking into account the effect of the operating mode as well as the role of the Ni/YSZ adhesion and the cermet microstructure. From this point of view, it could be possible to mitigate the Ni depletion by microstructural and material optimization.

\section{Acknowledgement}

The research leading of these results has received funding from the European Horizon 2020 - Research and Innovation Framework program (H2020-JTI-FCH-2015-1 and 2018-1) under grant agreement $n^{\circ} 735918$ (INSIGHT project) and $n^{\circ} 825027$ (AD ASTRA project). The work has also been partially supported by the French National Agency (ANR) (ECOREVE project). 


\section{Tables}

TABLE I. Elementary Electrochemical Reactions Considered in the Microscale Model for the Hydrogen Electrode.

\begin{tabular}{|c|c|c|}
\hline & Reaction & Kinetics \\
\hline 1c & $\mathrm{H}_{2} \mathrm{O}($ gas $)+\mathrm{s}_{\mathrm{Ni}_{\mathrm{N}}} \underset{\mathrm{k}_{\mathrm{H}_{2} \mathrm{O}, \mathrm{Ni}}}{\stackrel{\mathrm{k}^{\mathrm{des}}}{\rightleftarrows}} \mathrm{H}_{2} \mathrm{O}-\mathrm{s}_{\mathrm{Ni}}$ & $v_{\mathrm{H}_{2} \mathrm{O}, \mathrm{Ni}}^{\mathrm{ads}}=\mathrm{Sp}_{\mathrm{p}-\mathrm{Ni}} \cdot \Gamma_{\mathrm{Ni}} \cdot\left(\mathrm{k}_{\mathrm{H}_{2} \mathrm{O}, \mathrm{Ni}}^{\mathrm{ads}} \cdot \frac{\mathrm{p}\left(\mathrm{H}_{2} \mathrm{O}\right)}{\mathrm{p}_{\mathrm{ref}}} \cdot \theta_{\mathrm{SNi}_{\mathrm{Ni}}}-\mathrm{k}_{\mathrm{H}_{2} \mathrm{O}, \mathrm{Ni}}^{\mathrm{des}} \cdot \theta_{\mathrm{H}_{2} \mathrm{O}_{\mathrm{Ni}}}\right)$ \\
\hline $2 \mathrm{c}$ & 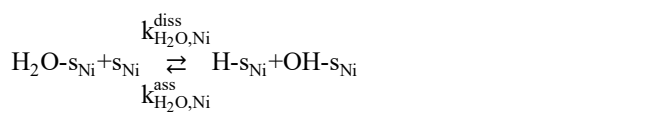 & $v_{\mathrm{H}_{2} \mathrm{O}, \mathrm{Ni}}^{\text {diss }}=\mathrm{Sp}_{\mathrm{p}-\mathrm{Ni}} \cdot \Gamma_{\mathrm{Ni}^{2}}^{2} \cdot\left(\mathrm{k}_{\mathrm{H}_{2} \mathrm{O}, \mathrm{Ni}}^{\text {dis }} \cdot \theta_{\mathrm{H}_{2} \mathrm{O}_{\mathrm{Ni}}} \cdot \theta_{\mathrm{S}_{\mathrm{Ni}}}-\mathrm{k}_{\mathrm{H}_{2} \mathrm{O}, \mathrm{Ni}}^{\text {ass }} \cdot \theta_{\mathrm{H}_{\mathrm{Ni}}} \cdot \theta_{\mathrm{OH}_{\mathrm{Ni}}}\right)$ \\
\hline $3 \mathrm{c}$ & $\mathrm{OH}-\mathrm{s}_{\mathrm{Ni}}+\mathrm{s}_{\mathrm{Ni}} \underset{\mathrm{k}}{\stackrel{\text { aHs }}{\text { aliss }} \underset{\mathrm{Nsi}}{\rightleftarrows}} \mathrm{H}-\mathrm{s}_{\mathrm{Ni}}+\mathrm{O}-\mathrm{s}_{\mathrm{Ni}}$ & $v_{\mathrm{OH}, \mathrm{Ni}}^{\mathrm{diss}}=\mathrm{Sp}_{\mathrm{p}-\mathrm{Ni}} \cdot \Gamma_{\mathrm{Ni}}^{2} \cdot\left(\mathrm{k}_{\mathrm{OH}, \mathrm{Ni}}^{\text {diss }} \cdot \theta_{\mathrm{OH}} \cdot \theta_{\mathrm{S}_{\mathrm{Ni}}}-\mathrm{k}_{\mathrm{OH}, \mathrm{Ni}}^{\text {ass }} \cdot \theta_{\mathrm{O}_{\mathrm{Ni}}} \cdot \theta_{\mathrm{H}_{\mathrm{Ni}}}\right)$ \\
\hline $4 c$ & $2 \mathrm{H}-\mathrm{s}_{\mathrm{Ni}} \underset{\mathrm{k}_{\mathrm{H}_{2}, \mathrm{Ni}} \underset{\mathrm{H}_{2}, \mathrm{Ni}}{\rightleftarrows}}{\stackrel{\text { ads }}{\rightleftarrows}} \mathrm{H}_{2}($ gas $)+2 \mathrm{~s}_{\mathrm{Ni}}$ & $v_{\mathrm{H}_{2}, \mathrm{Ni}}^{\mathrm{des}}=\mathrm{Sp}_{\mathrm{p}-\mathrm{Ni}} \cdot \Gamma_{\mathrm{Ni}}^{2} \cdot\left(\mathrm{k}_{\mathrm{H}_{2}, \mathrm{Ni}}^{\mathrm{des}} \cdot \theta_{\mathrm{H}_{\mathrm{Ni}}}^{2}-\mathrm{k}_{\mathrm{H}_{2}, \mathrm{Ni}}^{\text {ads }} \cdot \frac{\mathrm{p}\left(\mathrm{H}_{2}\right)}{\mathrm{p}_{\mathrm{ref}}} \cdot \theta_{\mathrm{S}_{\mathrm{Ni}}}^{2}\right)$ \\
\hline $5 c$ & 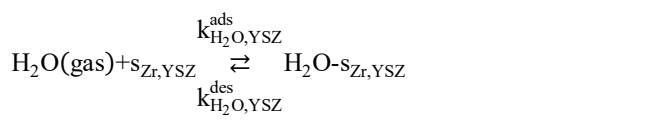 & $v_{\mathrm{H}_{2} \mathrm{O}, \mathrm{YSZ}}^{\mathrm{ads}}=\mathrm{Sp}_{\mathrm{p}-\mathrm{YSZ}} \cdot \Gamma_{\mathrm{YSZ}} \cdot\left(\mathrm{k}_{\mathrm{H}_{2} \mathrm{O}, \mathrm{YSZ}}^{\mathrm{ads}} \cdot \frac{\mathrm{p}\left(\mathrm{H}_{2} \mathrm{O}\right)}{\mathrm{p}_{\mathrm{ref}}} \cdot \theta_{\mathrm{SZr}_{\mathrm{Z}}}-\mathrm{k}_{\mathrm{H}_{2} \mathrm{O}, \mathrm{YSZ}}^{\mathrm{des}} \cdot \theta_{\mathrm{H}_{2} \mathrm{O}_{\mathrm{Zr}}}\right)$ \\
\hline $6 c$ & $\mathrm{H}_{2} \mathrm{O}-\mathrm{s}_{\mathrm{Zr}, \mathrm{YSZ}}+\mathrm{O}_{\mathrm{O}}^{\mathrm{x}}(\mathrm{YSZ})+\mathrm{s}_{\mathrm{Zr}, \mathrm{YSZ}} \underset{\mathrm{k}_{\mathrm{H}_{2} \mathrm{O}, \mathrm{YSZ}}}{\stackrel{\text { ass }}{\rightleftarrows}} \underset{\mathrm{k}_{\mathrm{H}_{2}, \mathrm{YSS}}^{\text {diss }}}{\rightleftarrows} 2 \mathrm{OH}^{\prime}-$ & $v_{\mathrm{H}_{2} \mathrm{O}, \mathrm{YSZ}}^{\text {diss }}=\mathrm{Sp}_{\mathrm{p}-\mathrm{YSZ}} \cdot \Gamma_{\mathrm{YSZ}}^{2} \cdot\left(\mathrm{k}_{\mathrm{H}_{2} \mathrm{O}, \mathrm{YSZ}}^{\text {diss }} \cdot \theta_{\mathrm{H}_{2} \mathrm{O}_{\mathrm{Zr}}} \cdot \theta_{\mathrm{sZr}_{\mathrm{Z}}}-\mathrm{k}_{\mathrm{H}_{2} \mathrm{O}, \mathrm{YSZ}}^{\text {ass }} \cdot \theta_{\mathrm{OH}_{\mathrm{Zr}}^{\prime}}^{2}\right)$ \\
\hline & $\mathrm{s}_{\mathrm{Zr}, \mathrm{YSZ}}+\mathrm{V}_{\mathrm{O}}(\mathrm{YSZ})$ & \\
\hline 1e & 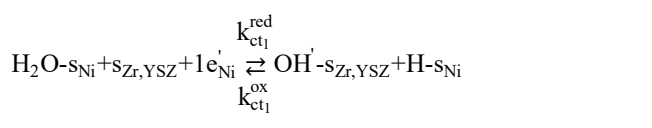 & 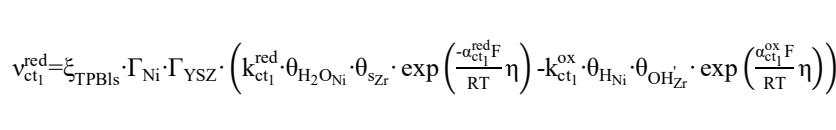 \\
\hline & $\mathrm{OH}^{\prime}-\mathrm{s}_{\mathrm{Zr}, \mathrm{YSZ}}+\mathrm{V}_{\mathrm{O}}^{*}(\mathrm{YSZ})+\mathrm{s}_{\mathrm{Ni}}+1 \mathrm{e}_{\mathrm{Ni}}^{\prime} \underset{\mathrm{k}_{\mathrm{ct} 2}^{\mathrm{ox}}}{\stackrel{\mathrm{k}_{\mathrm{ct}}}{\mathrm{red}}} \mathrm{H}-\mathrm{s}_{\mathrm{Ni}}+\mathrm{O}_{\mathrm{O}}^{\mathrm{x}}(\mathrm{YSZ})+\mathrm{s}_{\mathrm{Zr}, \mathrm{YSZ}}$ & 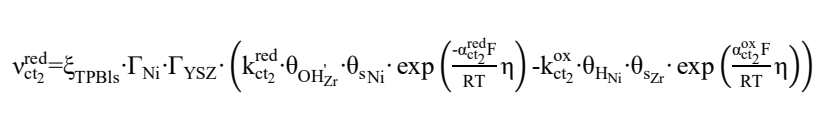 \\
\hline
\end{tabular}


TABLE II. Bulk properties of the Ni-YSZ extracted away from the electrode/electrolyte interface.

\begin{tabular}{|c|c|c|c|c|c|c|c|c|c|c|c|c|c|}
\hline Sample & $\begin{array}{c}\xi_{\text {TPBls }} \\
\left(\mu \mathrm{m}^{-2}\right)\end{array}$ & $\begin{array}{l}V f_{p} \\
(\%)\end{array}$ & $\begin{array}{c}V f_{Y S Z} \\
(\%)\end{array}$ & $\begin{array}{l}V f_{\mathrm{Ni}} \\
(\%)\end{array}$ & $\begin{array}{c}S p_{p-Y S Z} \\
\left(\mu \mathbf{m}^{-1}\right)\end{array}$ & $\begin{array}{l}S p_{p-N i} \\
\left(\mu m^{-1}\right)\end{array}$ & $\begin{array}{c}\text { SppsZ-Ni } \\
\left(\mu \mathrm{m}^{-1}\right)\end{array}$ & $\begin{array}{l}\overline{\mathbf{D}}_{\mathrm{m}, \mathrm{p}} \\
(\mu \mathrm{m})\end{array}$ & $\begin{array}{c}\overline{\mathbf{D}}_{\mathrm{m}, \mathrm{YSZ}} \\
(\mu \mathrm{m})\end{array}$ & $\begin{array}{l}\overline{\mathbf{D}}_{\mathrm{m}, \mathrm{Ni}} \\
(\mu \mathrm{m})\end{array}$ & $\begin{array}{c}\text { M- } \\
\text { factor }_{p} \\
(-)\end{array}$ & $\begin{array}{c}\text { M- } \\
\text { factor }_{\mathrm{YSZ}} \\
(-)\end{array}$ & $\begin{array}{c}\text { M- } \\
\text { factor }_{\mathrm{Ni}} \\
(-)\end{array}$ \\
\hline Cell-A Reference & 6.03 & 29.0 & 42.3 & 28.7 & 1.99 & 0.67 & 1.71 & 0.41 & 0.37 & 0.46 & 0.027 & 0.173 & 0.044 \\
\hline Cell-B Reference & 1.55 & 29.1 & 36.8 & 34.1 & 1.21 & 0.28 & 0.90 & 0.72 & 0.59 & 1.14 & 0.036 & 0.150 & 0.065 \\
\hline Cell-A1 Inlet & 4.26 & 26.9 & 42.7 & 30.4 & 1.89 & 0.41 & 1.55 & 0.44 & 0.39 & 0.62 & 0.034 & 0.186 & 0.038 \\
\hline Cell-A1 Center & 4.42 & 27.5 & 42.4 & 30.1 & 1.89 & 0.43 & 1.54 & 0.44 & 0.39 & 0.61 & 0.037 & 0.180 & 0.039 \\
\hline Cell-Al Outlet & 4.11 & 27.7 & 42.5 & 29.8 & 1.87 & 0.41 & 1.47 & 0.45 & 0.40 & 0.63 & 0.038 & 0.184 & 0.037 \\
\hline Cell-A2 Inlet & 4.40 & 25.3 & 44.9 & 29.8 & 1.90 & 0.45 & 1.52 & 0.40 & 0.41 & 0.61 & 0.024 & 0.207 & 0.039 \\
\hline Cell-B Active & 1.11 & 28.3 & 32.3 & 39.4 & 1.07 & 0.18 & 0.76 & 0.80 & 0.59 & 1.81 & 0.061 & 0.124 & 0.073 \\
\hline Cell-B Inactive & 1.14 & 32.1 & 30.6 & 37.2 & 1.07 & 0.26 & 0.60 & 0.84 & 0.63 & 1.93 & 0.079 & 0.103 & 0.055 \\
\hline
\end{tabular}




\section{Figures}

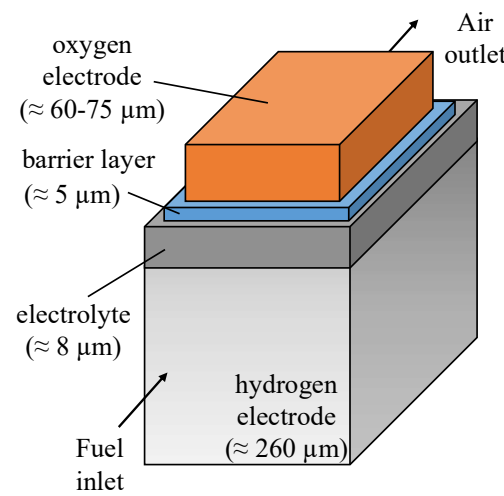

a)

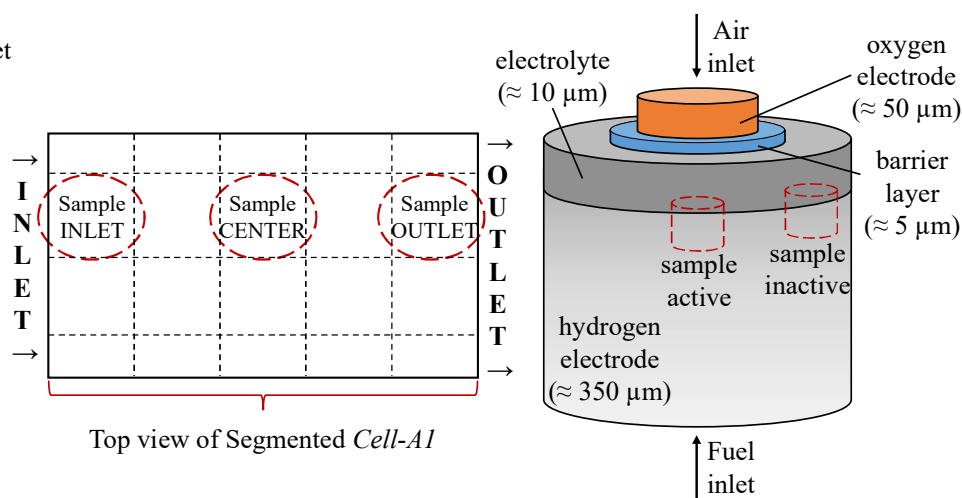

b)

c)

Figure 1. Schematic description of the analyzed cells: Dimensions and configuration of Cell$A$ (a) - Illustration of the sectors for Cell-A1 (b) -Dimensions and configuration of Cell-B (c). 


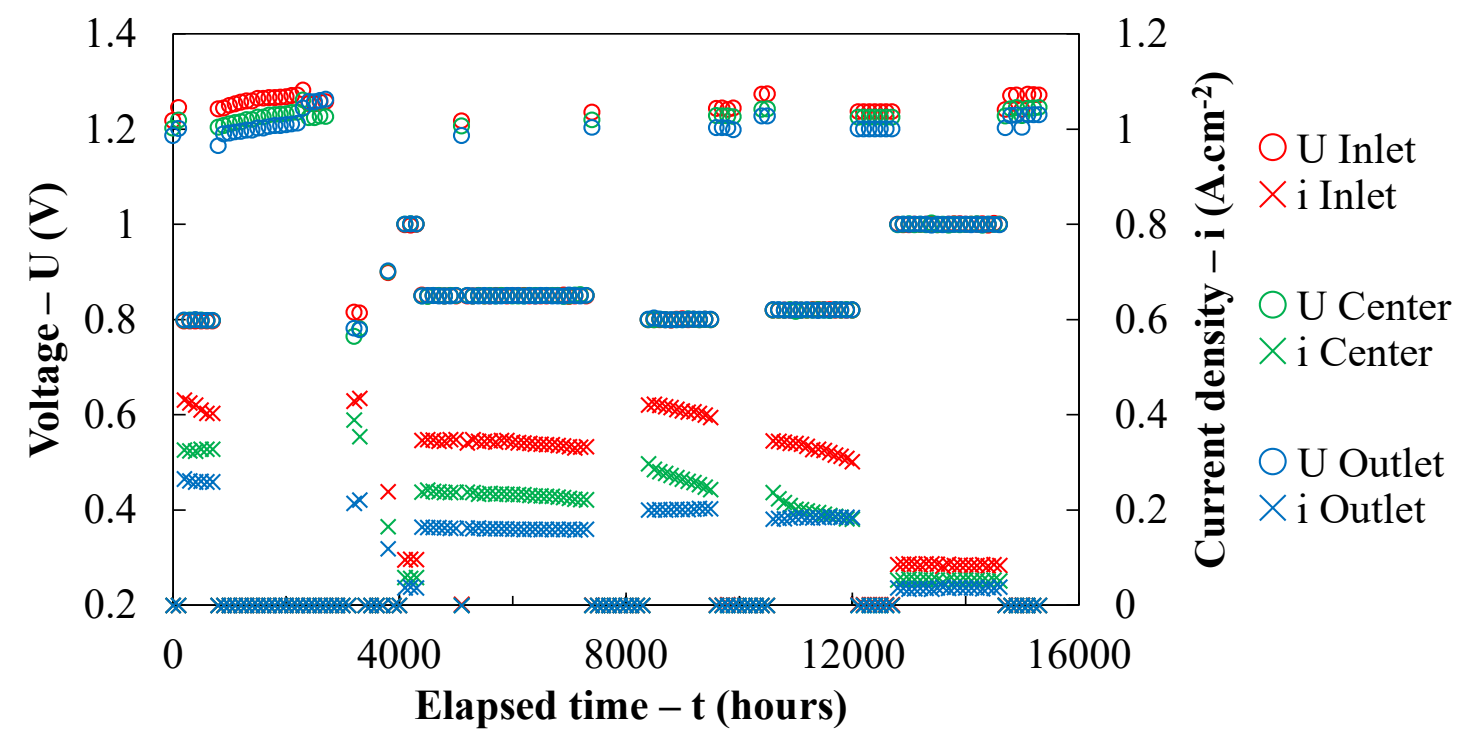

Figure 2. Experimental results for Cell-A1 aged in fuel cell mode for 15000 hours: Local voltages and current densities as function of time for the three segments analyzed. 


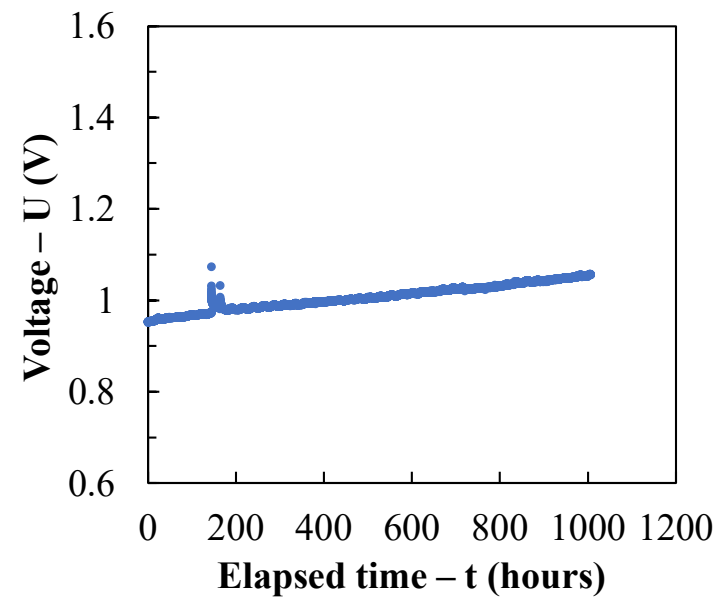

a)

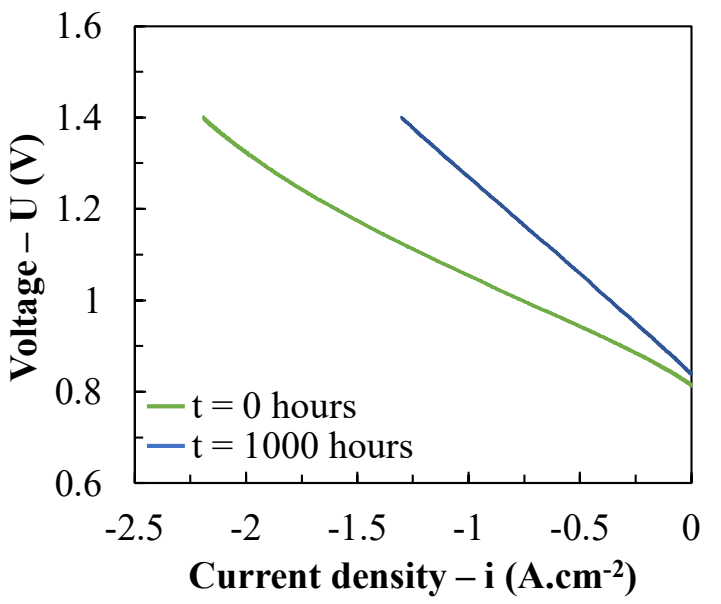

b)

Figure 3. Experimental results for Cell-B aged in electrolysis mode for 1000 hours: Durability curve at $800^{\circ} \mathrm{C}$ and $-0.5 \mathrm{~A} \cdot \mathrm{cm}^{-2}$ (a) - Comparison of the polarization curves recorded after the reduction and at the end of the experiment (b). 


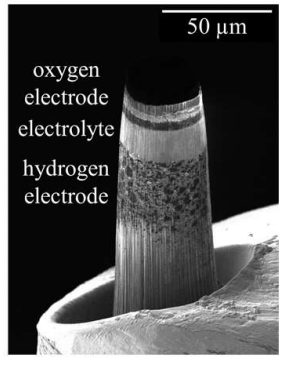

a)

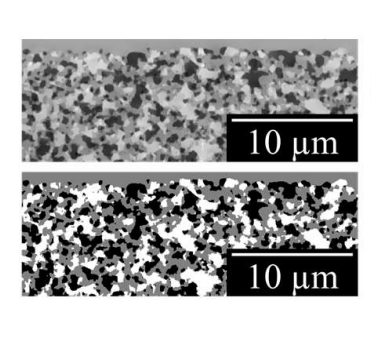

b)

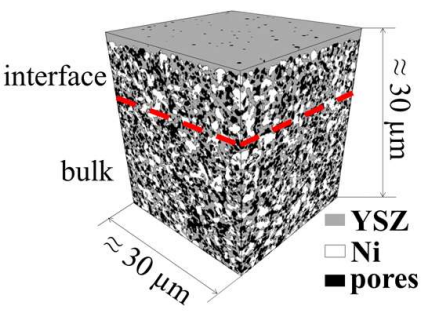

c)

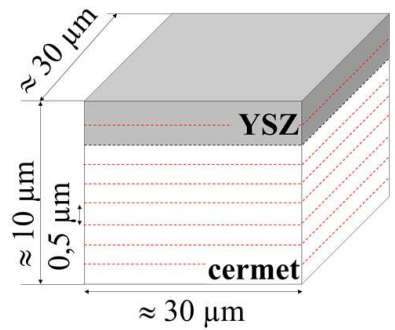

d)

Figure 4. Procedure for the sample preparation, reconstruction and analysis: Micro pillar of Cell-B Reference prepared with the pFIB (a) - Comparison of a 2D slice before and after the segmentation (b) - 3D segmented volume (c) - Illustration of the slice-by-slice approach for the computation of the local microstructural properties at the electrode/electrolyte interface (d). 


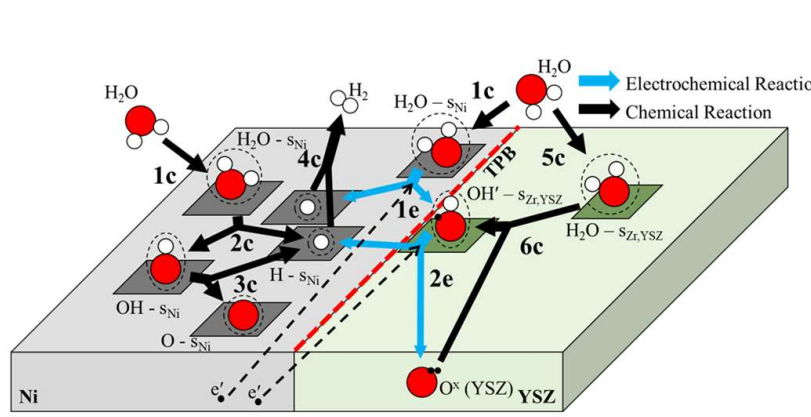

a)

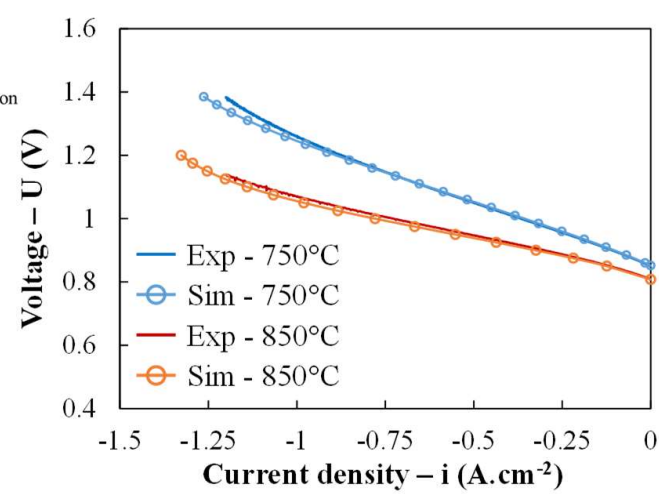

b)

Figure 5. Illustration of the electrochemical model: Elementary reactions considered in the elementary model for the hydrogen electrode (a) - Model validation on cell performances at $750^{\circ} \mathrm{C}$ and $850^{\circ} \mathrm{C}$ (b). 
a)

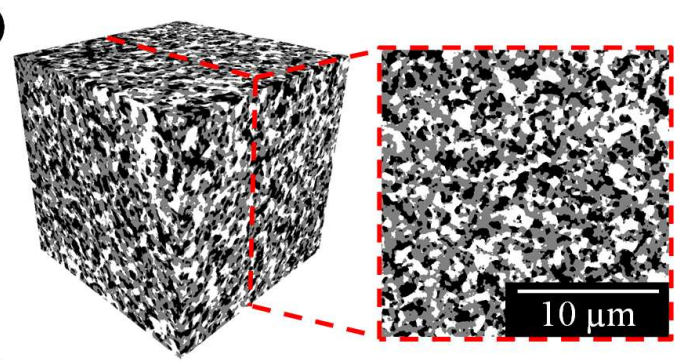

c)

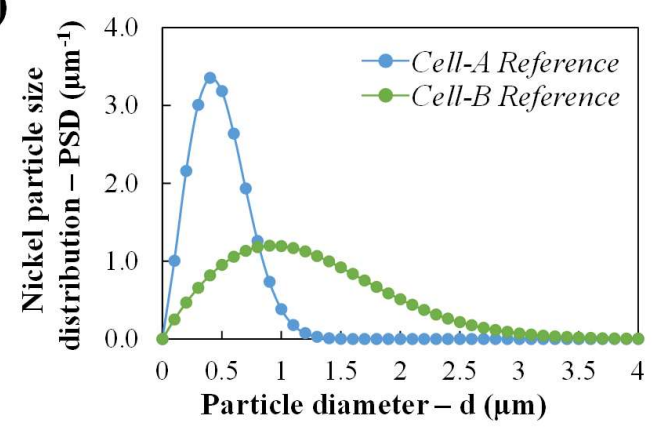

b)

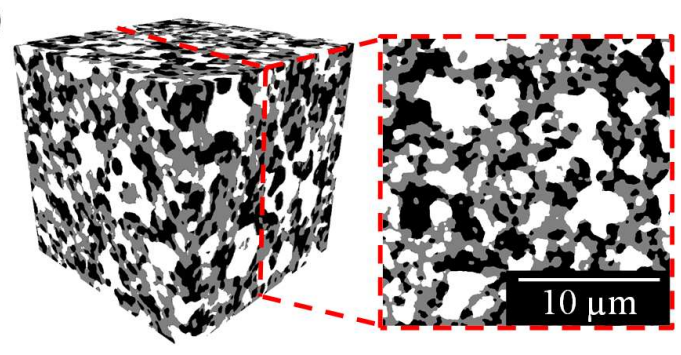

d)

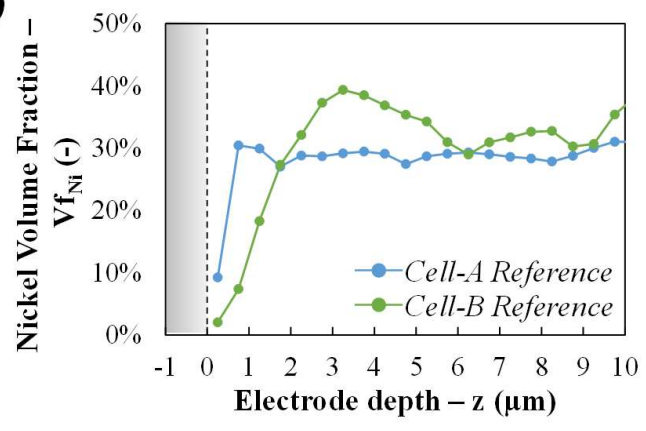

Figure 6. Comparison of the microstructural properties between the two types of reference cells: 3D rendering and 2D cross-section of Cell-A Reference (a) and Cell-B Reference (b) Nickel particle size distribution for the two types of reference cells (c) - Evolution of the $\mathrm{Ni}$ volume fraction for the two cells at the electrode/electrolyte interface (d) (White: Ni, Grey: YSZ, Black: Pores). 
a)

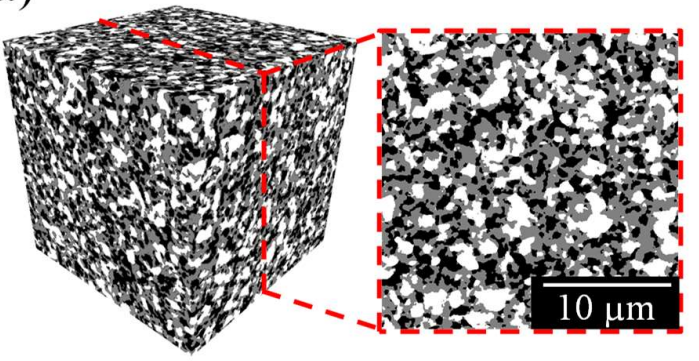

c)

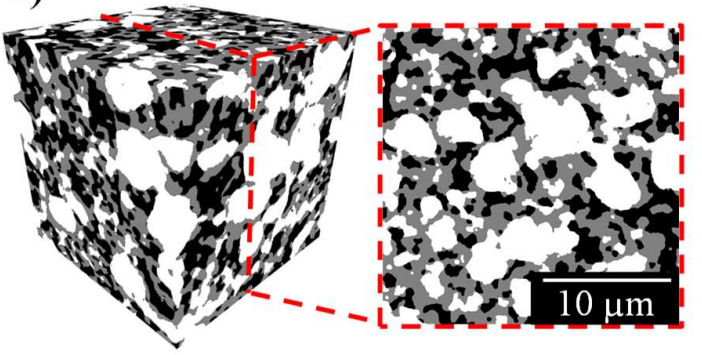

b)

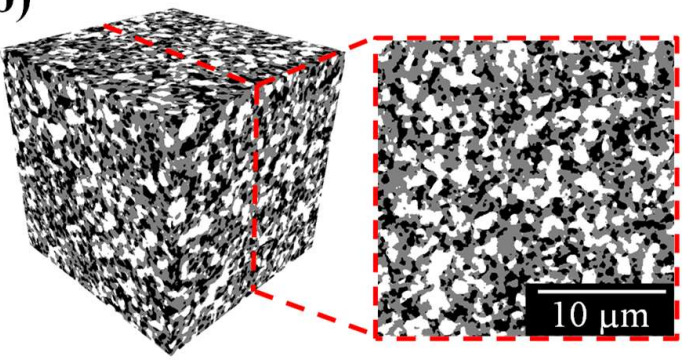

d)

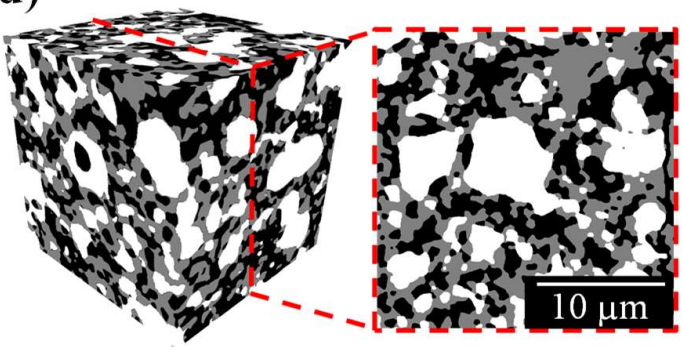

Figure 7. 3D segmented rendering and 2D cross-sections extracted for the bulk reconstructions of the aged samples: Cell-A1 Outlet (a) - Cell-A2 Inlet (b) - Cell-B Active (c) - Cell-B Inactive (d) (White: Ni, Grey: YSZ, Black: Pores). 
a)

b)

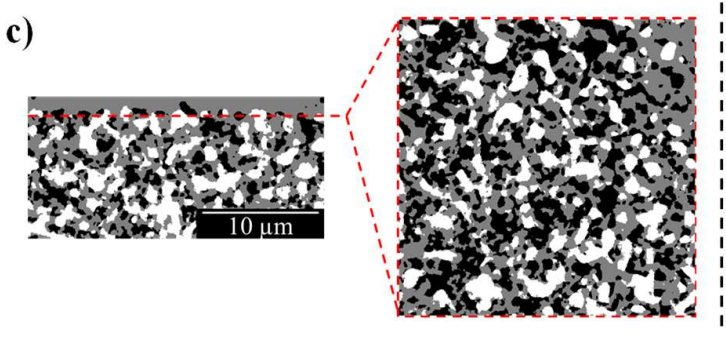

d)

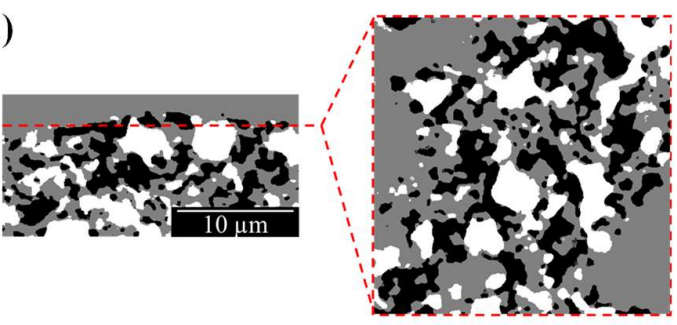

e)
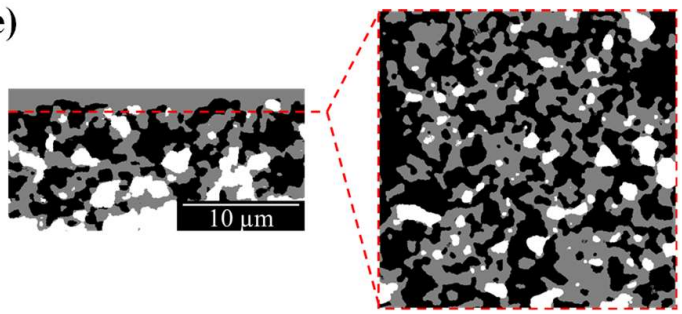

f)

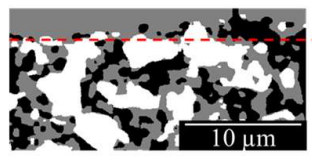

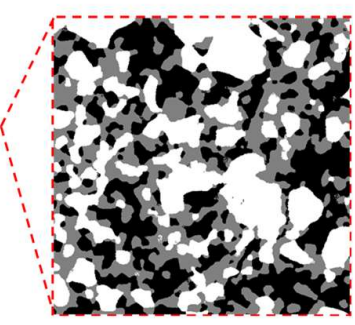

Figure 8. 2D images from the segmented volumes extracted parallel and perpendicular to the electrode/electrolyte interface: Cell-A Reference (a) - Cell-A1 Outlet (b) - Cell-A2 Inlet (c) Cell-B Reference (d) - Cell-B Active (e) - Cell-B Inactive (f) (White: Ni, Grey: YSZ, Black: Pores). 


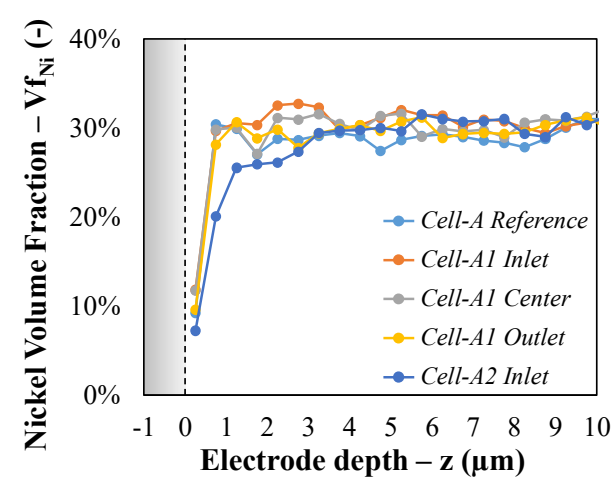

a)

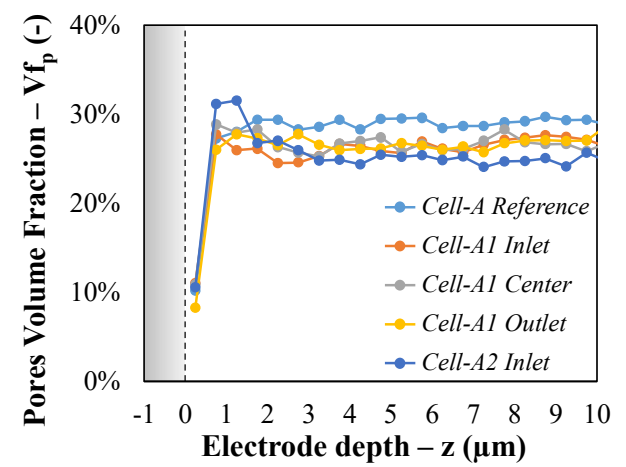

c)
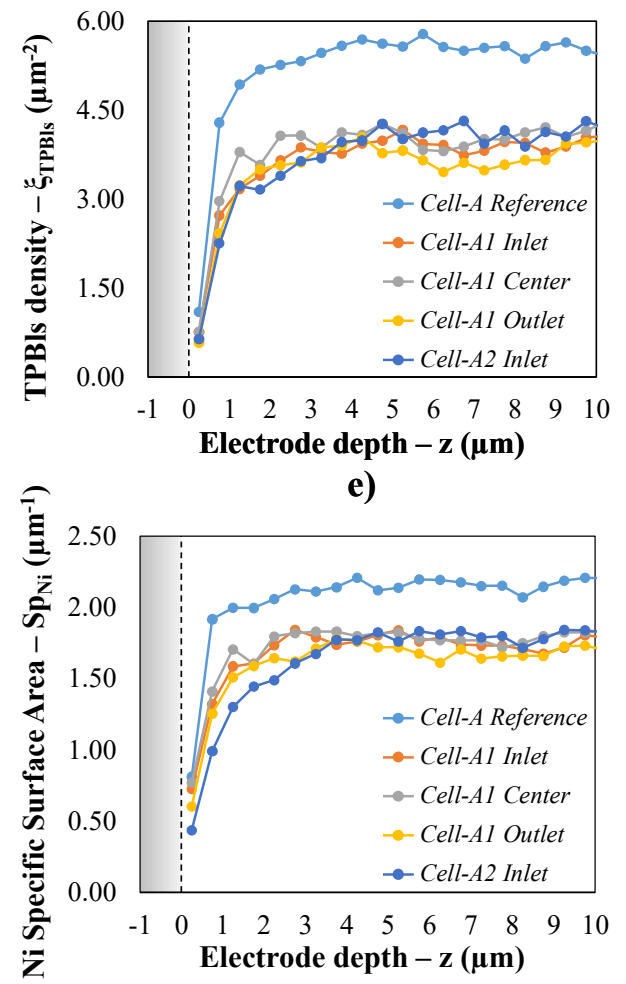

g)

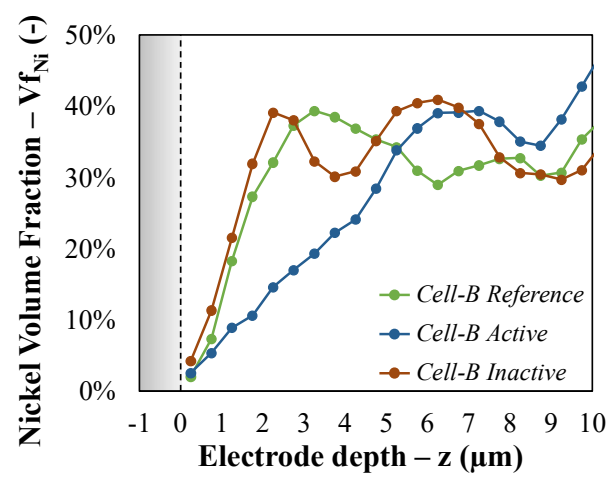

b)

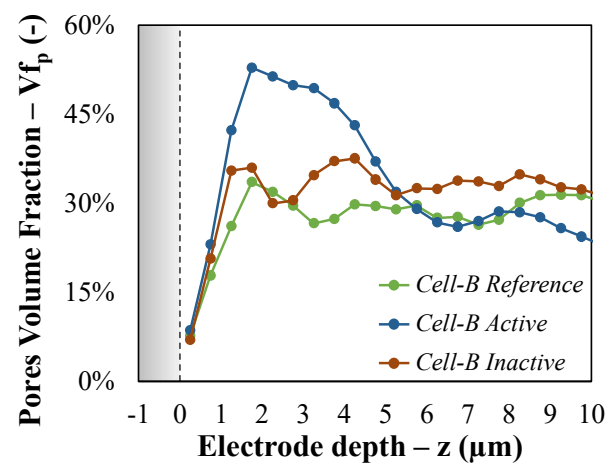

d)
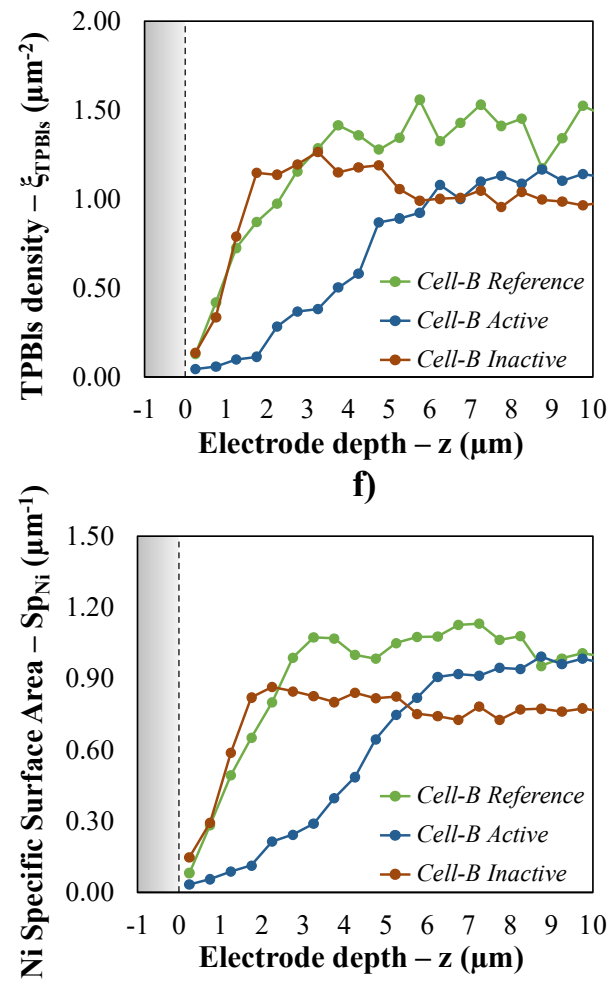

h)

Figure 9. Local microstructural parameters at the electrode/electrolyte interface for Cell- $A$ and Cell-B: Nickel volume fraction $(\mathrm{a}, \mathrm{b})$ - Pores volume fraction $(\mathrm{c}, \mathrm{d})-\mathrm{TPBls}$ density $(\mathrm{e}, \mathrm{f})-\mathrm{Ni}$ specific surface area $(\mathrm{g}, \mathrm{h})$. 


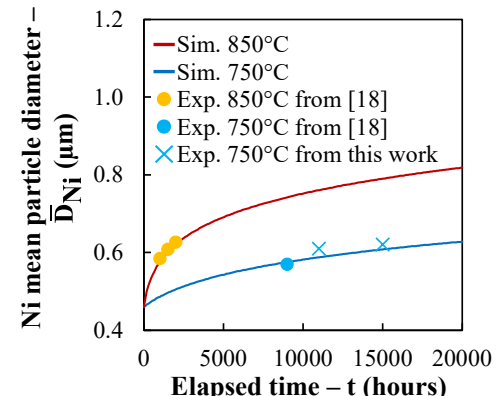

a)



d)

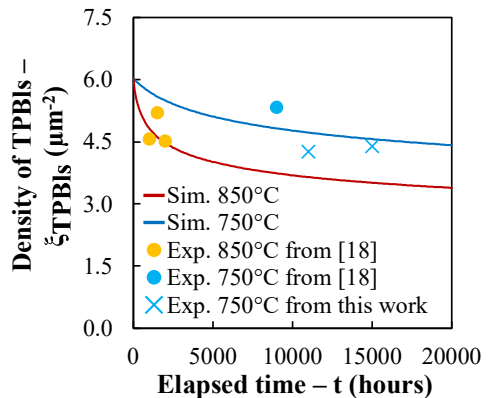

b)

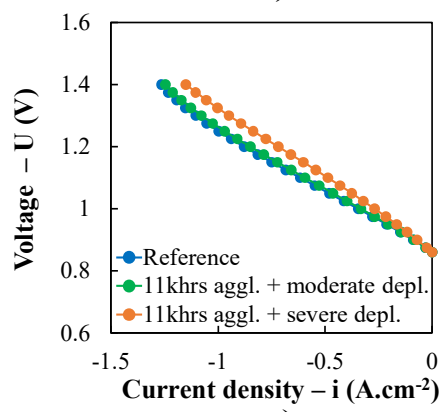

e)

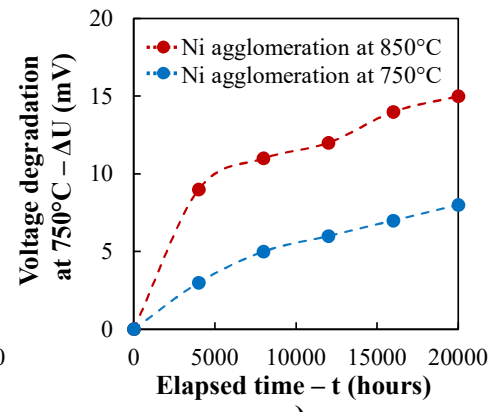

c)

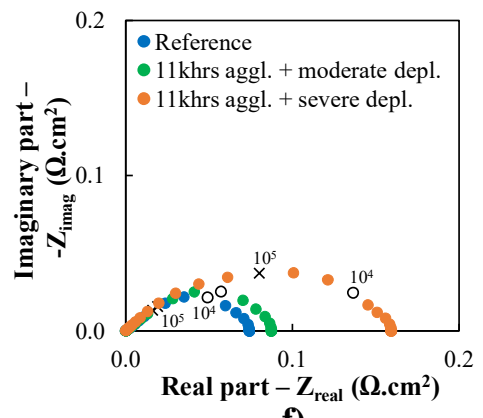

f)

Figure 10. Effects of the hydrogen electrode microstructural evolution on the electrode and cell performances: Increase of the Ni mean particle diameter associated to the Ni agglomeration (a) - Effect of the Ni agglomeration on the density of TPB1s (b) - Simulated voltage drop at $750^{\circ} \mathrm{C}$ and $-0.5 \mathrm{~A} . \mathrm{cm}^{-2}$ caused by $\mathrm{Ni}$ agglomeration at $750^{\circ} \mathrm{C}$ and $850^{\circ} \mathrm{C}$ (c) - Effect of the Ni depletion on the hydrogen electrode performances (d) and on the cell performances (e) Evolution of the EIS associated to the Ni depletion (f). 


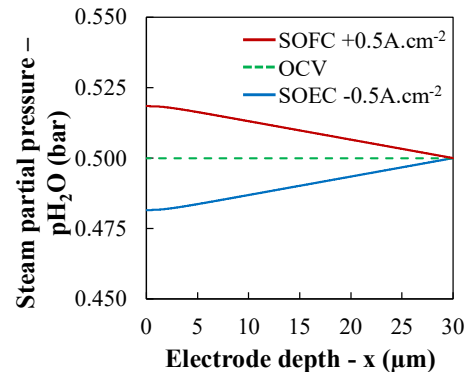

a)

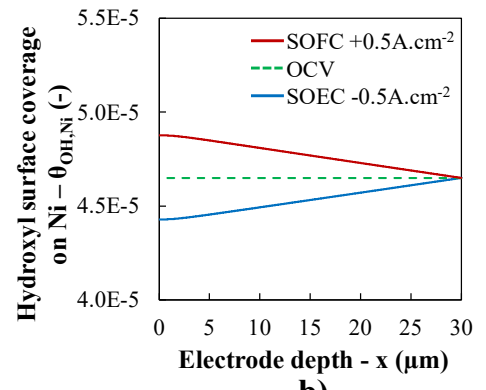

b)

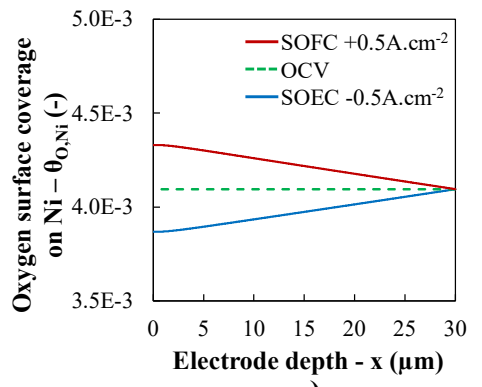

c)

Figure 11. Simulation results for the hydrogen electrode at $50 \% \mathrm{H}_{2}-50 \% \mathrm{H}_{2} \mathrm{O}$ and $750^{\circ} \mathrm{C}$ : Steam partial pressure (a), hydroxyl Ni surface coverage (b) and oxygen Ni surface coverage (c) as function of the position in the electrode at $+/-0.5 \mathrm{~A} . \mathrm{cm}^{-2}$. 


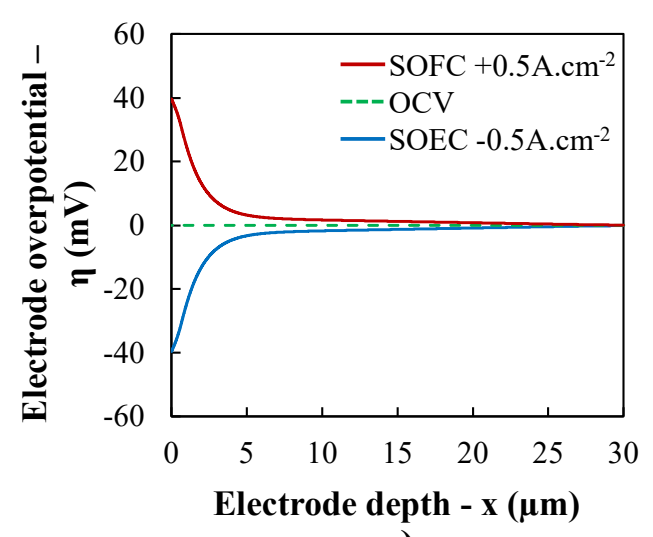

a)

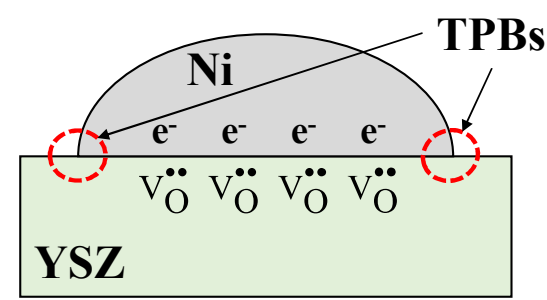

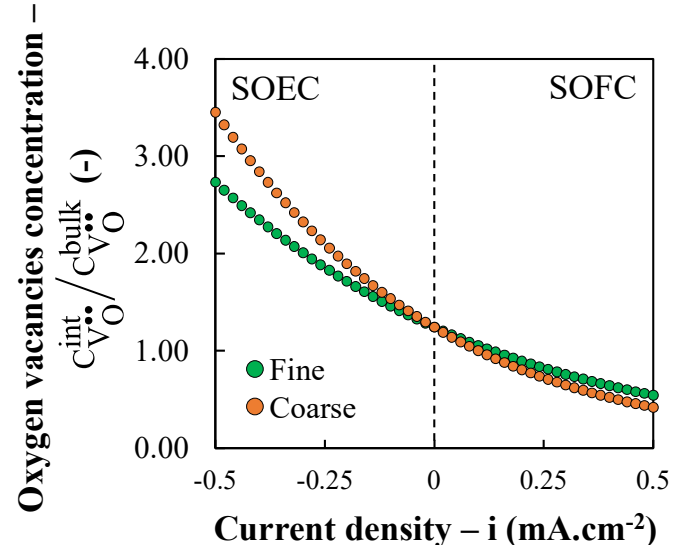

b)

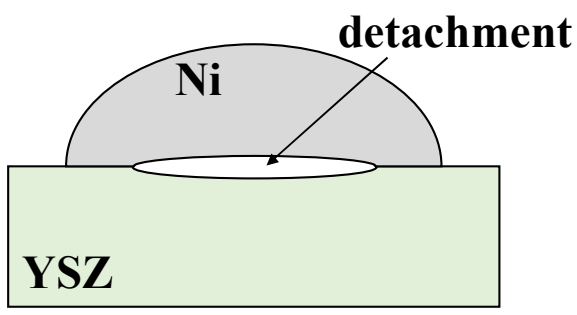

c)

Figure 12. Mechanism for Ni depletion: Electrode overpotential as function of the position in the electrode at $+/-0.5 \mathrm{~A} \cdot \mathrm{cm}^{-2}$ (a) - Normalized oxygen vacancies concentration in the YSZ at the electrode/electrolyte interface as function of the applied current density (b) - Proposed mechanism for the weakening of the Ni/YSZ interface (c). 


\section{References}

[1] J. Laurencin and J. Mougin, in Hydrogen Production by Electrolysis, 1st ed., A. GodulaJopek, Editor, p. 101 Wiley-VCH, (2015).

[2] K. Kendall, M. Kendall, High-Temperature Solid Oxide Fuel Cells for the 21st Century Fundamentals, Design and Applications, Elsevier Ltd. (2016).

[3] M. Lehner, R. Tichler, M. Koppe, Power-to-Gas: Technology and Business Models, Springer (2014).

[4] S.Y. Gómez, D. Hotza, Renew. Sustain. En. Rev., 61155 (2016).

[5] S.P.S. Shaikh, A. Muchtar, M.R. Somalu, Renew. Sustain. En. Rev., 511 (2015).

[6] V. Dusastre, J.A. Kilner, Solid State Ionics, 126163 (1999).

[7] E. Effori, H. Moussaoui, F. Monaco, R.K. Sharma, J. Debayle, Y. Gavet, G. Delette, G. Si Larbi, E. Siebert, J. Vulliet, L. Dessemond, J. Laurencin, Fuel Cells, 19429 (2019).

[8] J.T.S. Irvine, D. Neagu, M.C. Verbraeken, C. Chatzichristodoulou, C. Graves, M.B. Mogensen, Nat. Energy., 115014 (2016).

[9] M.S. Sohal, J.E. O’Brien, C.M. Stoots, V.I. Sharma, B. Yildiz, A. Virkar, J. Fuel Cell Sci. Technol., 9011017 (2011).

[10] T.L. Skafte, J. Hjelm, P. Blennow, C. Graves, EFCF Proc. B0501 (2016).

[11] K. Chen, S.P. Jiang, J. Electrochem. Soc., 163 F3070 (2016).

[12] M.S. Khan, S.B. Lee, R.H. Song, J.W. Lee, T.H. Lim, S.J. Park, Ceram. Int., 4235 (2016).

[13] P. Moçoteguy, A. Brisse, Int. J. Hydrogen Energy, 3815887 (2013).

[14] J. Laurencin, M. Hubert, D.F. Sanchez, S. Pylypko, M. Morales, A. Morata, B. Morel, D. Montinaro, F. Lefebvre-Joud, E. Siebert, Electrochim. Acta, 241459 (2017).

[15] D. Ferreira-Sanchez, D. Grolimund, M. Hubert, P. Bleuet, J. Laurencin, Int. J. Hydrogen Energy, 421203 (2017).

[16] A. Priebe, G. Goret, P. Bleuet, G. Audoit, J. Laurencin, J.P. Barnes, J. Microsc., 264 247 (2016).

[17] R. Knibbe, A. Hauch, J. Hjelm, S.D. Ebbesen, M. Mogensen, Green, 1141 (2011).

[18] M. Hubert, J. Laurencin, P. Cloetens, B. Morel, D. Montinaro, F. Lefebvre-Joud, J. Power Sources, 397240 (2018).

[19] P. Tanasini, M. Cannarozzo, P. Costamagna, A. Faes, J. Van Herle, A. Hessler-Wyser, C. Comninellis, Fuel Cells, 9740 (2009).

[20] M. Trini, P.S. Jørgensen, A. Hauch, J.J. Bentzen, P. V. Hendriksen, M. Chen, J. Electrochem. Soc., 166 F158 (2019). 
[21] C.E. Frey, Q. Fang, D. Sebold, L. Blum, N.H. Menzler, J. Electrochem. Soc., 165 F357 (2018).

[22] Q. Fang, C.E. Frey, N.H. Menzler, L. Blum, J. Electrochem. Soc., 165 F38 (2018).

[23] A. Faes, A. Hessler-Wyser, D. Presvytes, C.G. Vayenas, J. Van Herle, Fuel Cells, 9 841 (2009).

[24] F. Monaco, M. Hubert, J. Vulliet, D. Montinaro, J.P. Ouweltjes, P. Cloetens, P. Piccardo, F. Lefebvre-Joud, J. Laurencin, ECS Trans., 91653 (2019).

[25] E. Lay-Grindler, J. Laurencin, J. Villanova, P. Cloetens, P. Bleuet, A. Mansuy, J. Mougin, G. Delette, J. Power Sources, 269927 (2014).

[26] D. Kennouche, Y.C.K. Chen-Wiegart, K.J. Yakal-Kremski, J. Wang, J.W. Gibbs, P.W. Voorhees, S.A. Barnett, Acta Mater., 103204 (2016).

[27] D. Kennouche, Y.C.K. Chen-Wiegart, C. Riscoe, J. Wang, S.A. Barnett, J. Power Sources, 307604 (2016).

[28] S. De Angelis, P.S. Jørgensen, E.H.R. Tsai, M. Holler, K. Kreka, J.R. Bowen, J. Power Sources, 38372 (2018).

[29] A. Hagen, R. Barfod, P.V. Hendriksen, Y.-L. Liu, S. Ramousse, J. Electrochem. Soc., 153 A1165 (2006).

[30] Y.H. Lee, H. Muroyama, T. Matsui, K. Eguchi, J. Power Sources, 262451 (2014).

[31] M.P. Hoerlein, M. Riegraf, R. Costa, G. Schiller, K.A. Friedrich, Electrochim. Acta, 276162 (2018).

[32] Z. Jiao, N. Takagi, N. Shikazono, N. Kasagi, J. Power Sources, 1961019 (2011).

[33] D.G. Goodwin, H. Zhu, A.M. Colclasure, R.J. Kee, J. Electrochem. Soc., 156 B1004 (2009).

[34] M. Vogler, A. Bieberle-Hütter, L. Gauckler, J. Warnatz, W.G. Bessler, J. Electrochem. Soc., 156 B663 (2009).

[35] J. Mizusaki, H. Tagawa, T. Saito, T. Yamamura, K. Kamitani, K. Hirano, S. Ehara, T. Takagi, T. Hikita, M. Ippommatsu, S. Nakagawa, K. Hashimoto, Solid State Ionics, 70-71 52 (1994).

[36] S.P. Jiang, J. Mater. Sci., 383775 (2003).

[37] M.B. Mogensen, A. Hauch, X. Sun, M. Chen, Y. Tao, S.D. Ebbesen, K. V. Hansen, P. V. Hendriksen, Fuel Cells, 17434 (2017).

[38] G. Rinaldi, S. Diethelm, E. Oveisi, P. Burdet, J. Van herle, D. Montinaro, Q. Fu, A. Brisse, Fuel Cells, 17541 (2017).

[39] A. Hauch, P.S. Jørgensen, K. Brodersen, M. Mogensen, J. Power Sources, 1968931 (2011).

[40] G. Chen, G. Guan, Y. Kasai, A. Abudula, Int. J. Hydrogen Energy, 37477 (2012).

[41] A. Hauch, K. Brodersen, M. Chen, M.B. Mogensen, Solid State Ionics, 29327 (2016). 
[42] L. Holzer, B. Iwanschitz, T. Hocker, B. Münch, M. Prestat, D. Wiedenmann, U. Vogt, P. Holtappels, J. Sfeir, A. Mai, T. Graule, J. Power Sources, 1961279 (2011).

[43] A. Hauch, S.D. Ebbesen, S.H. Jensen, M. Mogensen, J. Electrochem. Soc., 155 B1184 (2008).

[44] J. Laurencin, D. Kane, G. Delette, J. Deseure, F. Lefebvre-Joud, J. Power Sources, 1962080 (2011).

[45] J. Laurencin, M. Hubert, K. Couturier, T. Le Bihan, P. Cloetens, F. Lefebvre-Joud, E. Siebert, Electrochim. Acta, 1741299 (2015).

[46] F. Monaco, J. Laurencin, E. Effori, M. Petitjean, L. Dessemond, F. Lefebvre-Joud, B. Morel, To be published.

[47] Z. Wuillemin, A. Müller, A. Nakajo, N. Autissier, S. Diethelm, M. Molinelli, J. Van, D. Favrat, EFCF Proc., B1009 (2008).

[48] C.A. Volkert, and A.M. Minor, MRS Bull., 32389 (2007).

[49] P.R. Munroe, Mater. Charact., 602 (2009).

[50] M. Hubert, J. Laurencin, P. Cloetens, J.C. da Silva, F. Lefebvre-Joud, P. Bleuet, A. Nakajo, E. Siebert, Solid State Ionics, 29490 (2016).

[51] L. Kwakman, G. Franz, M.M. Visser Taklo, A. Klumpp, P. Ramm, AIP Conf. Proc., 2691395 (2011).

[52] J. Villanova, J. Laurencin, P. Cloetens, P. Bleuet, G. Delette, H. Suhonen, F. Usseglio Viretta, J. Power Sources, 243841 (2013).

[53] M. Hubert, A. Pacureanu, C. Guilloud, Y. Yang, J.C. Da Silva, J. Laurencin, F. Lefebvre-Joud, P. Cloetens, Appl. Phys. Lett., 112203704 (2018).

[54] J. Laurencin, R. Quey, G. Delette, H. Suhonen, P. Cloetens, P. Bleuet, J. Power Sources, 198182 (2012).

[55] R. Quey, H. Suhonen, J. Laurencin, P. Cloetens, P. Bleuet, Mater. Charact., 7887 (2013).

[56] F. Usseglio-Viretta, J. Laurencin, G. Delette, J. Villanova, P. Cloetens, D. Leguillon, J. Power Sources, 256394 (2014).

[57] P. Perona, J. Malik, IEEE Trans. Pattern Anal. Mach. Intell., 12629 (1990).

[58] N. Otsu, IEEE Trans. Syst. Man. Cybern, C 62 (1979).

[59] H. Moussaoui, J. Laurencin, Y. Gavet, G. Delette, M. Hubert, P. Cloetens, T. Le Bihan, J. Debayle, Comput. Mater. Sci., 143262 (2018).

[60] F. Monaco, V. Tezyk, E. Siebert, S. Pylypko, B. Morel, J. Vulliet, T. Le Bihan, F. Lefebvre-Joud, J. Laurencin, Solid State Ionics, 319234 (2018).

[61] M. Hubert, PhD Thesis, Université Grenoble Alpes, Grenoble, France (2016).

[62] B. De Boer, PhD Thesis, University of Twente, Enschede, Netherlands (1998). 
[63] W.G. Bessler, J. Warnatz, D.G. Goodwin, Solid State Ionics, 1773371 (2007).

[64] J. Hanna, W.Y. Lee, Y. Shi, A.F. Ghoniem, Prog. Energy Combust. Sci., 4074 (2014).

[65] O.M. Pecho, O. Stenzel, B. Iwanschitz, P. Gasser, M. Neumann, V. Schmidt, M. Prestat, T. Hocker, R.J. Flatt, L. Holzer, Materials, 85554 (2015).

[66] H. Moussaoui, R.K. Sharma, J. Debayle, Y. Gavet, G. Delette, J. Laurencin, J. Power Sources, 412736 (2019).

[67] M.Z. Khan, M.T. Mehran, R.H. Song, J.W. Lee, S.B. Lee, T.H. Lim, J. Power Sources, 39194 (2018).

[68] H.P. Dasari, S.-Y. Park, J. Kim, J.-H. Lee, B.-K. Kim, H.-J. Je, H.-W. Lee, K.J. Yoon, J. Power Sources, 240721 (2013).

[69] A. Nechache, A. Mansuy, M. Petitjean, J. Mougin, F. Mauvy, B.A. Boukamp, M. Cassir, A. Ringuedé, Electrochim. Acta, 210596 (2016).

[70] M. Trini, PhD Thesis, Technical University of Denmark, Lyngbyn Denmark (2019).

[71] G. Rinaldi, A. Nakajo, P. Caliandro, L. Navratilova, J. Van herle, ECS Trans., 91641 (2019).

[72] M. Chen, Y.-L. Liu, J.J. Bentzen, W. Zhang, X. Sun, A. Hauch, Y. Tao, J.R. Bowen, P. Vang Hendriksen, J. Electrochem. Soc., 160883 (2013).

[73] H. Kishimoto, A. Suzuki, T. Shimonosono, M.E. Brito, K. Yamaji, T. Horita, F. Munakata, H. Yokokawa, J. Power Sources, 199174 (2012).

[74] D. Skarmoutsos, A. Tsoga, A. Naoumidis, P. Nikolopoulos, Solid State Ionics, 135 439 (2000).

[75] A. Tsoga, A. Naoumidis, P. Nikolopoulos, Acta Mater., 443679 (1996).

[76] T. Sasaki, K. Matsunaga, H. Ohta, H. Hosono, T. Yamamoto, Y. Ikuhara, Mater. Trans., 452137 (2004).

[77] A. Christensen, E.A. Carter, J. Chem. Phys., 1145816 (2001).

[78] M.G.H.M. Hendriks, J.E. Ten Elshof, H.J.M. Bouwmeester, H. Verweij, Solid State Ionics, 154-155 467 (2002). 